\title{
EL CANCIONERO SEVILLANO DE LA HISPANIC SOCIETY (CA. 1568)
}

Entre los valiosos manuscritos españoles que Archer M. Huntington compró al Marqués de Jerez de los Caballeros y que se encuentran ahora en la biblioteca de la Hispanic Society of America figura un tomo en $4^{\circ}$, encuadernado en "pasta anticuada", en cuyo lomo se lee Poesias del siglo xvi (sign. B2486). En un tiempo el ms. perteneció a Gallardo, quien numeró a lápiz sus folios ${ }^{1}$; pero ni Gallardo dejó constancia de este cancionero, ni nadie más, que sepamos, se ha ocupado de él. Aunque sólo fuera por su antigüedad y por su riquísimo contenido -más de $65^{\circ}$ textos poéticos-, merece ciertamente un examen detenido.

La descripción y el índice alfabético detallado que damos a continuación se han hecho a base del original y de una fotocopia. De. bemos a la amabilidad de los trustees de la H. S. A. y a la ayuda de Miss Clara Louisa Penney el haber podido realizar este trabajo.

El tomo, de $208 \times 153 \mathrm{~mm}$., consta de 299 folios $^{2}$, escritos en su mayoría a dos columnas. Los primeros 37 folios proceden posiblemente de fines del siglo xv o comienzos del xvi; contienen las Coplas de la Pasión y de la Resurrección del "Romano", o sea del Comendador Román, compuestas hacia 149o, y además (escritos por mano diferente) un poema de Pérez de Guzmán y dos del Marqués de Santillana, los tres sin atribución de autor. (Cf. núms. 227, 7o, 19,600 y 65 de nuestro Índice). Todo el resto del ms. es posterior y fue escrito, en su gran mayoría, por una sola persona ${ }^{3}$.

1 Según me hace saber don Antonio Rodríguez-Moñino, a la muerte de Gallardo (1852) el ms. pasó a manos de su sobrino Juan Antonio Gallardo. Éste lo vendió en Toledo el 25 de febrero de 1861 a don José Sancho Rayón, quien lo mandó encuadernar en Madrid hacia 1870 . A la muerte de Rayón (190o) lo adquirió el Marqués de Jerez de los Caballeros, para venderlo dos años después, con toda su biblioteca, al señor Huntington. En el Catálogo de mss. poéticos de la H.S.A., preparado por A. Rodríguez-Moñino y María Brey Mariño (de próxima publicación), nuestro ms. lleva el número VIII.

2 Gallardo se equivocó al numerar los folios, y después de escribir 280 siguió de nuevo con 271 ; sólo contó, pues, 289 folios. Previamente, el folio que debía seguir al 127 había quedado después del 162 ; en vez del número 163 , que le puso Gallardo, le hemos asignado el de 127 bis. (Las indicaciones correspondientes a 127 bis y a $281-299$ irán aquí entre corchetes).

3 Puede verse la letra del anónimo compilador en la lámina que aquí incluimos. Algunas poesias (o incluso estrofas) parecen escritas por otra mano. 
Aquí y allá se intercalan varias páginas en blanco y otras, escritas por diferentes manos, que contienen textos en prosa (algunos de ellos en latín), cuentas y apuntes varios, notaciones de melodías y copias de escrituras notariales ${ }^{4}$. Estas últimas permiten fijar el lugar y la fecha aproximada en que fue compilado el cancionero. Van firmadas por un bachiller Francisco de Medina, "ciuis hispalensis publicus notarius autoritate apostolica"s. Varias veces se menciona en ellas - como también en la composición núm. 364- la ciudad de Sevilla. Las fechas fluctúan entre $155^{8}$ y $15^{68}$. Fuera de las copias de escrituras aparecen algunas otras fechas, casi todas comprendidas dentro del período mencionado; la última está a la cabeza del fol. $188 \mathrm{v}$ : es el año tope de 1568 , varias veces citado en el ms., y que por ello podemos considerar como fecha aproximada de la composición del cancionero. Hay pruebas de otro orden que nos acercan también a ese año: por lo menos desde el fol. 76 , en que figura por primera vez una poesía de la Diana de Montemayor, el ms. debe ser posterior a 1559 (fecha de la edición príncipe de la obra), y posterior a ${ }^{1} 564$ por lo menos desde el fol. 197 , donde aparece una composición de la Diana de Gil Polo.

La gran mayoría de las composiciones poéticas de nuestro cancionero son villancicos y canciones; junto a ellas aparecen, en menor medida, otras formas de la escuela tradicional: coplas reales, castellanas, de arte menor y de pie quebrado, redondillas, glosas en dobles quintillas, romances, perqués. Pero no faltan algunas muestras de poesía italianizante: octavas, liras, sextetos-lira, tercetos, cuartetos y sobre todo sonetos (véase el Indice de formas métricas al final de este trabajo). Los textos se agrupan en cuatro secciones: dos de

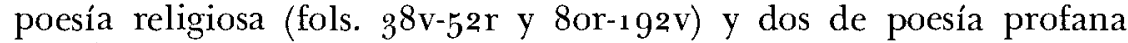

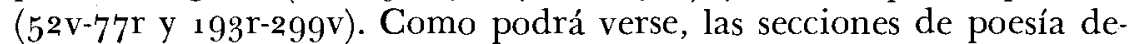
vota alternan con las de versos humanos, y ambos tipos ocupan un número casi igual de folios. Curiosa simetría en un cancionero que, a todas luces, no estaba destinado a la publicación, sino al simple entretenimiento de su compilador.

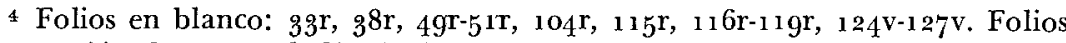
con notación de una melodía sin letra: $77 \mathrm{v}, 119 \mathrm{v}-120 \mathrm{r}$. Cuentas y otros apuntes:

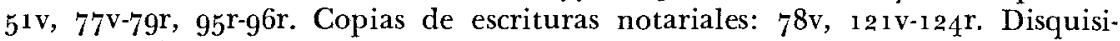
ciones en latín y español sobre gramática latina: 97v-102r. Otros apuntes y ejercicios escolares en latín: $102 \mathrm{v}-103 \mathrm{v}, 104 \mathrm{v}, 113 \mathrm{v}, 114 \mathrm{r}, 115 \mathrm{v}$. Copias de cartas en versión bilingüe, latina y española: 108r-11 gr. Exposición (en español) de un método para calcular las fiestas religiosas movibles (escrito en 1560): $10_{5} \mathrm{r}^{-10} \mathrm{7v}$.

5 Asi en el fol. $121 \mathrm{v}$. Valdría la pena seguirle la pista a este homónimo, conterráneo y coetáneo del famoso humanista hispalense. Quizá se refiera al notario la anotación no firmada del fol. 95r: "Rescibi el grado de bachiller a sejs dias del mes de abril de 1552 años era miercoles diomelo el maestro fray nicolas de salas siendo rector fray viceinte Carrillo y conciliarios fray gon[z]alo de arsiniega y fray gregorio Casuella". Evidentemente ese grado de bachiller fue otorgado en el Colegio Mayor de Santo Tomás, en Sevilla. 


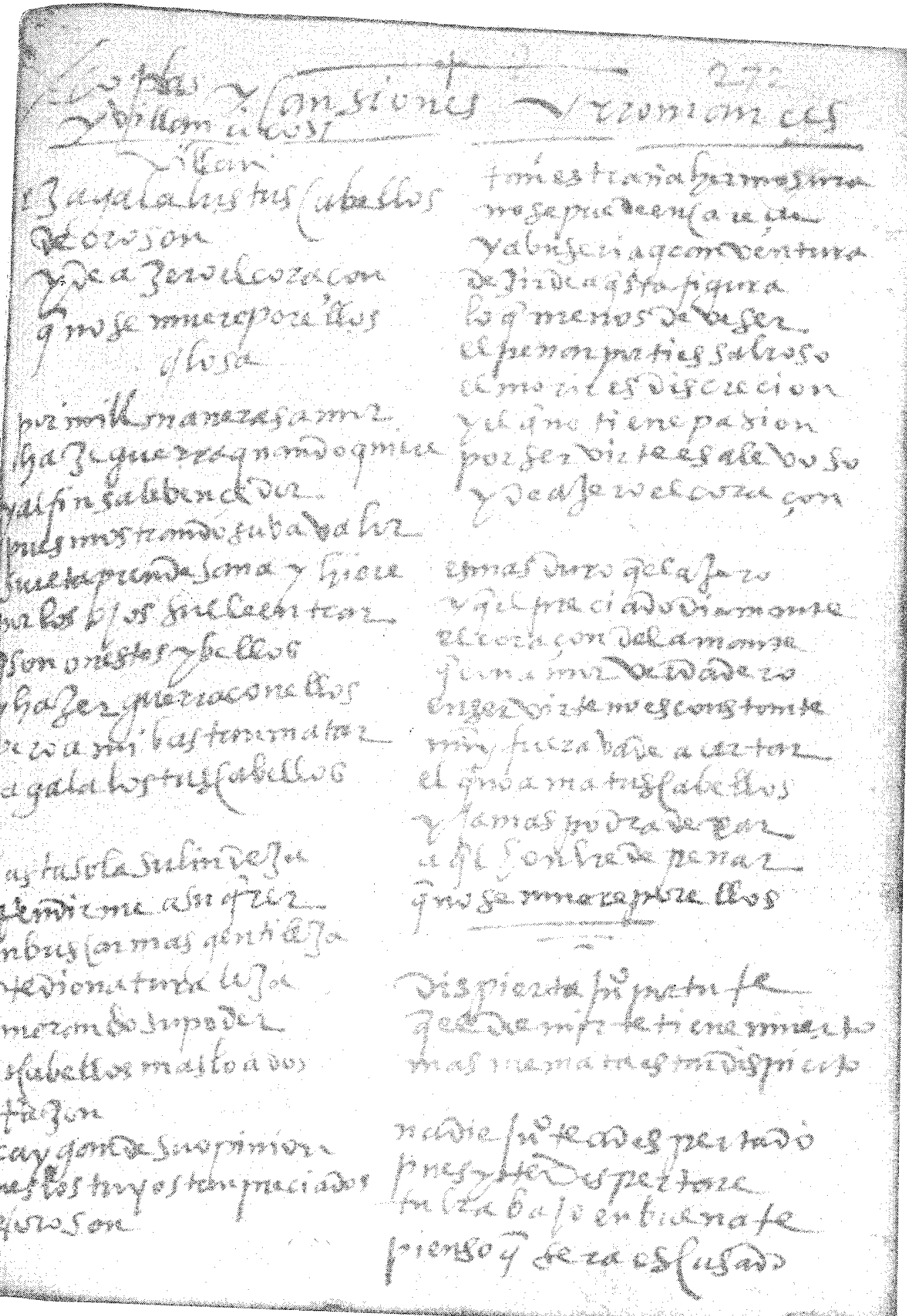

Cancionero sevillano de la Hispance society,

Gallardo (en realidad, fol. 282r).
Gún la numeración de 

Éste era, por lo visto, un buen conocedor de la poesía castiza. Aunque escribía rápidamente, a veces omitiendo alguna palabra o letra, se le ve consciente de las formas poéticas y escrupuloso en la separación de versos y estrofas. Al mismo tiempo es notoria su escasa familiaridad con la poesía italianizante: muchos endecasílabos están defectuosos. Parece evidente, por algunas "correcciones de autor" y espacios dejados en blanco para completar poesías o estrofas, que varias composiciones del ms. son obra del compilador mismo. A juzgar por la escasa inspiración de esos textos (núms. 21, 73, 126, 287, $292,308,340,398,5^{10}$ y $5^{81}$ de nuestra lista), el compilador era uno de aquellos "versificadores hebenes y chirles" que pululaban en la Sevilla de entonces ${ }^{6}$.

Sin duda, el cancionero nos da en cierto modo un índice de los gustos de esos seudo-literatos sevillanos durante el tercer cuarto del siglo xvI, de su tradicionalismo en cuanto a formas y concepciones poéticas, de su débil e inexperto flirteo con la poesía al modo italiano; además, de sus poetas preferidos. Las poesías no llevan nombre de autor ${ }^{7}$. Hemos identificado a los autores seguros o probables de unos setenta textos. De Jorge de Montemayor hay 26 poesías, posiblemente tomadas de alguna edición de su Cancionero y de la Diana; le sigue en frecuencia Gregorio Silvestre ( 17 textos), cuyas poesías corrían entonces manuscritas (la primera edición, póstuma, es de 1582). Otros poetas representados en el cancionero -cada uno con dos o tres textos- son Diego Hurtado de Mendoza, Pedro de Padilla, Gutierre de Cetina, Ramírez Pagán, Gil Polo (véase, al final, el Indice de autores). Extraña encontrar sólo una composición del sevillano Baltasar del Alcázar, y absolutamente ninguna de Fernando de Herrera, que ya en ${ }_{15} 69$ tenía fama de "divino".

Muchos de los villancicos pertenecen a ese enorme caudal de poesías fugaces que, como bien mostrenco, emigraban de un cartapacio manuscrito a otro, sufriendo continuos cambios, y que aparecían eventualmente impresos en alguno de los cancionerillos tan en boga por esos años. Así, hemos encontrado varias coincidencias entre nuestro tomo y el ms. 314 de la B. N. P., el Cancionero llamado Flor de enamorados (Barcelona, 1562), los cancionerillos publicados por Timoneda en $\mathbf{1 5 7 3}$, la Flor de romances y glosas, canciones $y$ villancicos... (Zaragoza, 1578), las compilaciones de Lucas Rodríguez $\left(15^{8} 5\right)$ y de Juan López de Úbeda $\left(1579,15^{82}\right)$, etc. Las coincidencias no son nunca absolutas; casi siempre hay divergencias en

6 Véase F. Ronríguez Marín, Luis Barahona de Soto, Madrid, 19o3, pp. 124 ss.

7 Salvo las dos menciones del "Romano" en la parte más antigua del ms., la atribución a un tal "Galindo" de la composición núm. 462 y la precisión "otras de Diana" (la de Montemayor) que antecede al núm. 4or. La anotación "de Pedro de Padilla", en el núm. 44, fue escrita por el Marqués de Jerez de los Caballeros. 
el número y orden de las estrofas, y mayor o menor cantidad de variantes textuales.

Debido a esa movilidad de villancicos y canciones, hemos creído conveniente dar en nuestro Indice, no sólo el texto íntegro del estribillo, sino además el primer verso de cada una de las estrofas, en el orden en que figuran. Lo hemos hecho con todos los villancicos de tema profano; en los de tema religioso, que no solían gozar de amplia divulgación, nos limitamos a indicar el estribillo, el comienzo de la primera estrofa y el número de coplas (entre paréntesis). De las glosas, reproducimos el estribillo y los dos primeros versos glosadores. En el caso de los sonetos y de las composiciones en octavas, liras, sextetos-lira, cuartetos, tercetos, redondillas, coplas reales y castellanas, etc., damos los dos primeros versos y el último. Las poesías que hemos encontrado en fuentes impresas se citan aquí sólo por su comienzo; lo mismo los veintisiete romances del ms., publicados por Paciencia Ontañón de Lope en NRFH, 15 (1961). Por razones de espacio no señalamos muchas fuentes en que hemos encontrado estribillos de nuestro cancionero seguidos de estrofas diferentes.

La mayoría de las composiciones van encabezadas en el ms. por la palabra otras, que no importaba consignar; los títulos referentes a la forma poética o al tema (soneto, Del Sacramento, etc.), que encabezan a algunas, se indican en cursiva después de los versos copiados. Señalamos la forma métrica siempre que no se trate de un villancico o canción en sus formas más típicas (ABBA cddccBBA..., ABAB cdcddBAB. .., etc.).

En la transcripción de los versos hemos respetado la ortografía del original, resolviendo las abreviaturas, supliendo las cedillas que faltan y modernizando la puntuación, la acentuación y el uso de mayúsculas. Para poder mantener el orden alfabético según la ortografía moderna, hemos hecho al comienzo de algunos versos ligeras alteraciones, que señalamos en cursiva (Cuando, por Quando; Hay, por Ay; De $u$ na, por De vna, etc.).

Empleamos las siguientes abreviaturas:

Antol.: Dámaso Alonso y José Manuel Blecua, Antologia de la poesía española. Poesia de tipo tradicional, Madrid, 1956.

Canc. Elvas: $O$ cancioneiro musical e poético da Biblioteca Públia Hortênsia [en Elvas], ed. M. Joaquim, Coimbra, 1940.

Canc. general: Cancionero general de Hernando del Castillo [1511], Bibliófilos Españoles, Madrid, 1882.

Canc. Medinaceli: Cancionero musical de la Casa de Medinaceli, ed. M. Querol Gavaldá, Barcelona, 1949-1950.

CeJador: Julio Cejador y Frauca, La verdadera poesia castellana. Floresta de la antigua lírica popular, Madrid, 1921-1930.

Cetrina, Obras: Gutierre de Cetina, Obras, ed. J. Hazañas y La Rúa, Sevilla, 1895 .

“237 sonnets": R. Foulché-Delbosc (ed.), “237 sonnets", RHi, 18 (1908), 488-618. 
Flor de enamorados: Cancionero llamado Flor de enamorados [Barcelona, 1562], ed. A. Rodríguez-Moñino y D. Devoto, Valencia, 1954.

Flor 1578: Flor de romances y glosas, canciones y villancicos... [Zaragoza, 1578], ed. A. Rodríguez-Moñino, Valencia, 1954.

Galeas: Francisco Galeas [monje de la Cartuja de Sevilla, 1567-1614], Poesias espirituales y representaciones sacras dramáticas, ms. del siglo xvn (H.S.A.).

Diego Hurtado de Mendoza: Diego Hurtado de Mendoza, Obras poéticas, ed. W. I. Knapp, Madrid, 1877 .

P. LAínez: Pedro Laínez, Obras, ed. J. de Entrambasaguas, Madrid, 1951.

LÓPEZ DE UBEDA, Cancionero: Juan López de Ubeda, Cancionero general de la doctrina christiana [1579], Alcalá, 1586.

Montemayor, Cancionero 1932: Jorge de Montemayor, El cancionero, ed. A. González Palencia, Madrid, 1932.

Montemayor, Diana: Id., Los siete libros de la Diana, ed. F. López Estrada, Madrid, 1946 .

Montemayor, Las obras: Id., Las obras, Anvers, 1554.

Montemayor, Segundo cancionero: Id., Segundo cancionero, Anvers, $155^{8}$.

Ontañón: Paciencia Ontañón de Lope, "Veintisiete romances del siglo xvi", NRFH, 15 (1961), 180-192.

Pliegos poéticos B.N.M.: Pliegos poéticos góticos de la Biblioteca Nacional, Madrid, 1957-1961.

Ramírez Pagán, Floresta: Diego Ramírez Pagán, Floresta de varia poesia [Valencia, 1562], ed. A. Pérez Gómez, Barcelona, $195^{\circ}$.

Silvestre: Gregorio Silvestre, Las obras, Lisboa, 1592.

Timoneda, Truhanesco, Guisadillo de amor: Juan Timoneda, Cancioneros llamados Enredo de amor, Guisadillo de amor y El truhanesco [1573], ed. A. Rodríguez-Moñino, Valencia, 1951.

Margit Frenk Alatorre

El Colegio de México.

\section{INDICE DEL CANGIONERO}

1. A caça salía Dina, / la hija de[l] gran Jacob... (rromançe): 278r-v. (Publicado por OnTAÑón, p. 187).

2. A correr, correr, zagales, / [g]ozaréis cosas divinales. // -Dinos qué viste, Tenorio (8 coplas zejelescas): $87 \mathrm{v}$.

3. A Dios te quieras quedar, / carillo, buen conpañero, / a Dios te quieras quedar, / que me fino, que me muero. // 1) Solo muero por amores, 2) Hallarás en [mi] çurrón: [294]v $s$.

4. ¿A dó mirastes, ojos desdichados... (soneto): 225v. (Publicado como de Juan de Almeida en Anales Salmantinos, 2, 1929, p. 235).

5. A la gala de las dos, / Madre y Hija soberana, / a la gala de Sant'Ana / y de la Madre de Dios. // Nunca tal madre se vio (3) (de Santa Ana): $145 \mathrm{v}$.

6. A la gala del Garçón, / a la fe, / que si yo pulidico vengo, / más garrido bolveré. // Vengo alegre y muy contento (2): $44 \mathrm{v}$.

7. A la que es Virgen y madre / vamos [a] adorar, / que bien sé el aguilando / que nos a de dar. // Darnos a muy cierto (6): $174 \mathrm{v} s$.

8. A la tierra voy / y del cielo vengo: / si no son amores, / no sé qué me tengo. // Vengo desd'el cielo (3): 43v. (Versión a lo divino del núm. 9; cf. núm. 158). 
9. A la villa voi, / de la villa vengo: / si no son amores, / no sé qué me tengo. // 1) A la villa fueron, 2) Siento vn mal extraño, 3) Si afioxa el dolor, 4) Quiero declararme: 24or-v. (Con las dos primeras coplas, en Canc. Elvas, p. 177. Cf. núms. 8, 10, 11 y $\left.15^{8}\right)$.

10. A la villa voy... // 1) A la villa fueron $(=9)$, 2) Por vna zagala, 3) Siento vna pasión, 4) $\mathrm{Si}$ acaso es amor, 5) $\mathrm{Va}$ mi pensamiento, 6) Pena y discontento: $248 \mathrm{v}$.

11. A la villa voy... (=9). // 1) Por mi zagalilla, 2) Anda mi ganado, 3) En mi mesmo apero, 4) Tengo aborrescido, 5) Ay, mi Dios, quán bellos: 242r-v.

12. - ¿A quién amas, di, zagal? / - A ti, pulida pastora. / -Lizonja es ésa Pascual. / -Verdad te digo, señora. // 1) -Pues ¿cómo yo no e sabido, 2) Yo no entiendo al coraçón: 7 ir.

13. - ¿A quién buscas, Amor? -Busco a Marfira... (soneto): 225r. (De MosTemayor: Segundo cancionero, $115 \mathrm{r}$; publicase como de Juan de Alaidia en Anales Salmantinos, 2, 1929, p. 228).

14. - ¿A quién parís, Virgen pura? / -A vn honbre, tanbién a Dios. / $-\mathrm{Si}$ ese mismo os hizo a vos, / bien podéys parir segura. // En el acuerdo divino (4): $94 \mathrm{r}$.

15. A solas en vn monte tran[s]portado / está el gran capitán de los menores... mas en sus pies y manos y costado (Soneto a Sant Francisco): 223v.

16. A su alvedrío y sin horden alguna / lleva Adán con duelos su ganado...

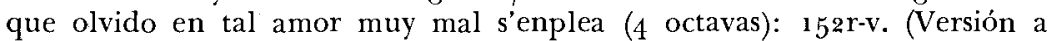
lo divino de 17 ).

17. A su alvedrío y sin orden alguna / lleva vn pastor por Duero su ganado... huya de ver alguno a Calatea (7 octavas): $26_{5}$ r-266r. (Los cuatro primeros versos están, con música polifónica, en Canc. Medinaceli, $\mathbf{n}^{0} 4^{1}$. - El núm. 626 es réplica de este poema, el cual aparece glosado en el núm. 18 y vuelto a lo divino en el 16).

18. [A su albedrío y $\sin$ orden alguna... $(=17)$ ] // Rriberas de vn rrío está vn pastor echado [sic],/ al qual rrindió el amor y la fortuna... (16 cuartetos y una octava): 6or-6ir. (Glosa de las dos primeras octavas del $17 \mathrm{y}$ reproducción, con variantes, de su tercera octava).

19. A ti adoramos, Dios, / a ti, Señor, confesamos... a quien tu justizia espanta (coplas de arte menor; El Te Deu[m] La[u]damus): 33v-34r. (De Hernán Pérez de Guzmán: Canc. general, núm. 40).

20. A ver al Niño y María / van Domingo, Gil y Bras, / tañendo el rrabel Tomás, / cantan con grande alegría. // Dexan todo su ganado (6) (al tono "Términos lleva Maria"): $188 \mathrm{v}$. (Contrahechura del 565).

21. A vos, preciosa lira, / que vais a ser de Dios dulçe ynstrumento... mas libres en Jesús crucificado (6 liras): $184 \mathrm{v}$. (Podría ser del compilador).

22. Abaxóse el sacro sacre / a la paloma sin hiel, / abaxóse el sacro sacre, / y ella hizo preza en él. // Como Adán, padre primero (6): 162r-v.

23. Acudid al alma, fe, / al alma no la dexéis, / mirá que la cativéis. // Contra el alma hazen guerra (2): $43 \mathrm{r}$.

24. - ¿Adónde vais, Señora, / madre de mi Dios? / - Voy del suelo al cielo / a rrogar por vos. // Dond'es vuestra yda (6): 179v.

25. Adurmi[ó]se mi lindo amor / del sueño de amor vencido / y quedóseme adormido / sobre el pecho del Señor. // El amor suele causar (1) (Otras del mismo [S. Juan Evangelista]): 14ov. (Versión a lo divino del 26).

26. Adurmióse mi lindo amor, / siendo del sueño vencido, / y quedóseme adormido / debaxo de vn cardo corredor. // 1) Debaxo del pensamiento, 2) Nunca tal sueño se vio, 3) No sé cómo puede ser, 4) Muchas vezes me a jurado: $262 \mathrm{v}$ s. (Cf. 25).

27. Afuera, consejos vanos, / que dispertáis mi dolor, / no me toquen vuestras 
manos, / qu'en los consejos de amor / los que matan son los sanos. // No vengáis a me matar, / contentamientos pasados... (glosa): 259v.

28. Agua va, / hela va, / cata do va; / guárdese quien debaxo está... el que en hablarte e gastado (lexía; diálogo de insultos; perqué de $103 \mathrm{vs}$.): $72 \mathrm{~V} s$.

29. Aguarda, Silvia, ya tú, si quisieres, / aguarda, pues te Ilamo, sé piadosa... (2 cuartetos, sin duda de un soneto): 27 or.

30. Águila caudal, que con gran buelo / secretos muy secretos penetraste... tú, quien más que mi vida y alma quiero (soneto Al Evangelista S. Juan): 2241 .

31. -A $h$, carillejo, ahao. / - ¿Qué quieres, Mingo, di? / -Que me digas cómo / nasçe Dios aquí. // Di cómo es posible (4): 93r-v. (Versión a lo divino del 33 ; cf. 32 ).

32. -Ah, carillejo, ahao. / ¿Qué quieres, Mingo, di? / -Que me digas digas / si Dios nasció aquí. // En tan gran pobreza (5): 9iv. (Versión a lo divino del 33 ; cf. 31 ).

33. -A h, carillo, ahao. / ¿Qué quieres, Mingo, di? / -Vengo enamorado, / ¿qué será de mí? // 1) Sábete que ayer, 2) Qué te rrespondió, 3) Andas aburrido, 4) O, que es muy hermosa: [295]v. (Cf. 31 y 32).

34. -A $h$, muerte, vida mía. - ¿Quién me llama? / -Quien de amores tuyos muere. -O, qué locura $[s i c] .$. que lo eres para mí, pues no as Ilegado (soneto Del honbre y la muerte): $76 \mathrm{r}$.

35. -Ah, Pelayo, que desmayo. / -Benito, dime de qué. / -No sé más de que yo muero, / muero, Pelayo, a la fe. // 1) No te desmayes, zagal, 2) No estés tan aquillotrado, 3) Carillo, según oteo, 4) Pues di si la muerte as vido, 5) Sabrás que mis ojos vieron: $200 v$.

36. -A h, Pelayo, que desmayo. / ¿ ¿De qué, di?... [296]v. (De Montemayor: Las obras, $18 \mathrm{v} s$.).

37. Ah, perro color de breva, / sal acá, sal acá de la cueva. // Lucifer desconocido ( 7 estrofas zejelescas): $86 \mathrm{v}$.

38. A $h$, Silvia, ¿por qué huyes, Silvia, espera, / espera a tu Lucino que te Ilama... el cuerpo yaze de mi fiel Silvano (soneto): 270 .

39. Al Niño desnudo al frío / la Virgen vía llorar, / y ella le dezía: / -Vida y lunbre mía, / callá y tomad de mamar. // EI Niño rrezi[é]n nascido (3): $92 \mathrm{v} s$.

40. Al Pastor bendito / que guarda el ganado / Iuego se lo vide / que era enamorado. // En ver que venía (5): 16or. (Cf. 319).

41. Al que de vos se partió, / señora, no ay pena ygual. . .: 62r. (En Silvestre, $110 v$ s.).

42. Al que vos, mi entendimiento / por fe veis en este altar / mis ojos lo an de mirar. // A puesto a su rrostro vn velo (2): $43 \mathrm{r}$.

43. Al tienpo que ya el sol está tenplado / salió Belisa al canpo sola vn día... a todos dais la vida y a mí muerte (soneto): $226 \mathrm{r}$.

44. Al valiente don Manuel, / que de León se dezía... (rromançe): 59v. (Como lo dice una nota manuscrita del Marqués de Jerez de Ios Caballeros, el romance es de Pedro de Padilla; cf. Ontañón, p. 191).

45. Alçé los ojos a veros, / baxélos después que os vi...: [29o]v s. (De MoNTEMAYor, Diana, III; pp. 148-149).

46. Alegráos, ánima mía, / y alas de mi coraçón, / bolad en contenplación / selestial. . que esperamos (perqué de 56 vs.; De San Juan Evangelista): 139 v s. (Cf. 48 ).

47. Alegráos, Rreyna del cielo, / y dadnos, señora mía, / parte de vuestra alegría. // $\mathrm{O}$, divino rregozijo (5): $87 \mathrm{r}-\mathrm{v}$.

48. Alegráos, Señora mía, / y alas de mi coraçón, / bolad en contenplación. // Con la fe y entendimiento (3): $87 \mathrm{v}-88 \mathrm{r}$. (Cf. 46 ). 
49. Alma, mi querida, / si te adornas, yré / a comer deste pan que da vida / a los hijos de fe. // Si la hermosura (3) (Del Sacramento): 141r.

5o. Alma, pon en Dios los ojos / y no quieras otro amor. // Alma de Dios escogida (4 estrofas de dísticos con encadenamiento y estribillo constante): $45^{\mathrm{r}}$.

51. Allí y aquí es eternal / y el mesmo que permaneçe, / y si la vista falleçe / supla la fe divinal. // En nuestra sustancia rruda (3): $47 \mathrm{v}$.

52. Ámalo, qu'es Dios ynfinito, / quiérelo, qu'es tu Rredentor. // El sacro verbo encarnado (7 cuartetas encadenadas): $144 \mathrm{v} \mathrm{s}$.

53. Amó Dios tanto a Maria / por ser tan santa donzella, / que a querido en este día / nascer hecho honbre della. // La que de gracia es dotada (3) (al tono de "Gila", o sea del núm. 552): 189v s.

54. Amor, cuerpo de Dios con quien os hizo, / ¿en qué ley halláys vos que esté obligado... que acá quiçá sm vos vivir podremos (soneto): 76 r. (Coimcide básicamente con TıMONEDA, Buen aziso y portacuentos, xxv; cf. $R H i$, 24, 1911, 194-195).

55. Amor, dezíme vn lenguaje: / ¿quién es aquel capilludo... el consonante a tasajo (Pregunta en 3 coplas reales, más una de respuesta): $280 v$.

56. Amor le hizo nascer / a Dios pobre y en el suelo, / y amor le puso aquel velo / por que le podáis comer. // Amor le puso cuydado (3): 42v.

57. Amor loco, / yo por vos y vos por otro...: [293]r. (De la Diana de MoNTEMAYOR, I; p. 57).

58. Amor, ¿si avéis de quedar / o si me avéis de olvidar? // 1) El alma y el coraçón, 2) Triste de mí, que no sé: [296]r. Amor, yo os juro a Dios que si os cogiese: cf. 627 .

59. Amores, amores, / de la hermosa Donzella, / que parió a Dios eterno / y quedó más bella. // La muger primera (6): $167 \mathrm{v} s$. (Cf. 6o).

6o. Amores, amores / de la parida Donzella, / pues que Dios eterno / los tuvo della. // Amor muy dichoso (4): 8gv. (Cf. 59).

61. Amores me an de matar, / bien lo sé, / mas tengo de porfiar. // 1) El que espera de alcançar, 2) Siendo como soys sim par, 3) Avnque sepa no alcançar, 4) Porfía es dificultosa, 5) Donde está el peligro cierto: $277 \mathrm{v} s$.

62. Ana, qué dura estás, qué porfiada, / a fe qu'es burlería... que aquei que más le rruegan más s'estiende (3 sextetos-lira): $220 v$.

63. Ándense todos tras mí, / [q]ue al que más muestro querer, / en dexándole de ver / no me acuerdo si le vi. // 1) Ándese tras mí la gente, 2) Y al que muestro más favor: $199 \mathrm{v}$.

$\hat{o}_{4}$. Ángel, di de dó partiste, / que tan buena nueua truxiste. // Vine de to alto del cielo (4): $120 \mathrm{v}$.

65. Ames el rrodante zielo / tornará manso y quieto... olbidare (todo tacnado): 37 v. (Son las dos primeras coplas de la canción de Santillana, Canc. general, núm. 55).

66. Aquel gran Dios de Isrrael / que del Padre sale y viene / oy cunple el voto solene / que David hizo por éi. // A David le prometió (3) (al tono de "Ysabel"): i łov. (Contrahace la famosa canción rufianesca "¿Quién te me enojó, Isabel...?").

67. Aquel que de Dios Padre fue enbiado, / aquel que fue antes sancto que nascido... ny tal qual la mereçes y quisiera (soneto al Baptista): 224r.

68. Aquel sí viene, no viene, / aquel sí sale, no sale, / no ay manjar que se le yguale / de cuantos el amor tiene. // 1) Aquel tardar el galán, 2) Aquel estar asomada, 3) Aquel aver prometido, 4) Aquel estar en la calle, 5) Aquel estar sin sosiego, 6) Aquel pasar por la puerta: 25iv $s$.

69. Aquella linda zagala / que a mí me dará la pena, / pues la vi, / Dios que la hizo tan buena / no la hiziera vna ora mala / para mí. // 1) Com- 
púsola Dios tan bella, 2) Dios que la quiso criar, 3) Zagala de gran valor, 4) Y tú, Amor, que no as querido, 5) Ya casi desconfiado: 262v.

7o. Aquella muerte y Pasión / de nuestro santo Cordero... nel pecado ( $\mathrm{La}$ rresurrezión de nuestro Señor Jesús Christo trobada por el COMENDADoR RoMÁN): $16 \mathrm{v}-32 \mathrm{v}$. (Cf. núm. 227. También aquí se omite la Introducción a los Reyes, de 4 coplas).

71. Aquí yaze sepultada / vna parlera señora... (Epitaphio a la sepoltura de vna monja muy parlera, en una copla castellana): $222 \mathrm{r}$ y 223r. (Está, con variantes, en la Floresta de Santa Cruz, XI, 3, núm. 923).

72. Armas de amor, señora, son tus ojos, / con ellos prendes, matas (a) quien te mira... que no con arco y flecha, qu'es mentira ( 5 tercetos): $216 \mathrm{r}$.

73. Arronjéle cientas nuevas / al demonio de pesar, / arronjómelas y arronjéselas / y tornómelas [a] arronjar. // Aronjéle ser parida (5): 153v. (Versión a lo divino de Antol., 236; probablemente del compilador).

Así andavan en Çamora: cf. 164 .

74. Así se consuela / quien sus madexas quema...: 63r-v. (Atribuido a Gregorio Silvestre en el Cartapacio de Morán de la Estrella, $11 \mathrm{v}$; impreso por M. L. Guzmán en RHi, 35, 1915, 442-444).

75. -Asienta, Gil, [el] pie llano, / que tu perdición me admira. / - A la mi fe, Bras hermano, / quien bien ama poco mira. // 1) No sé qué diga de verte, 2) Mal hazes en desdeñar, 3) Flaquezas de coraçón, 4) Pues bivir vida penada: [293]v $s$. (Cf. 76 y 77 ).

76. -Asienta, Gil, el pie llano... $(=75)$. // O, qué trocado te veo, / Gil amigo, y sin conorte... (glosa): [299]v.

77. -Asienta, Gil, el pie Ilano, / tu grande plazer me admira. / -El gozo que es más que humano, / carillo, jamás se olvida. // Ten cuenta con $\mathrm{t}[\mathrm{u}]$ ganado (6): [127 bis]v. (Versión a lo divino de 75 ).

78. Aunque estáys vestido, / Dios, de mi sayal, / por ser por amores, / n'os paresçe mal. // Dios como pastor (3) (folías al tono de "O, qué grande conbite"): 1 gov y -con melodía y sólo la $1^{\text {a }}$ estrofa- [281]v.

79. Aunque lo ves manso niño, / vestido de puro amor, / guárdeos Dios de su furor. // Humana trae la librea (2): 16ir.

80. Aunque n'os miro, señora, / sabe Dios / si las vezes que sospiro / son por vos. // 1) Sabe Dios que q[u]and'os veo, 2) Quedóse en mi fantasía, 3) Bastó para no perderos: 222r-v. (Cf. 197).

81. Aunque yo quiero ser beata, / el amor, el amor me lo desbarata (sólo eso): $229 \mathrm{v}$.

82. ¡Ay, ay, qué dulçe sabor / tenéys, mi Dios y Señor, / ay, ay, qué dulce sabor! // EI dulçe maná sabroso (3): $44 \mathrm{v} s$.

83. ¡Ay, cadenas de amar, / quán mala[s] soys de quebrar! // 1) Ay, amorosas cadenas, 2) Ay, niñerías y antojos, 3) Ay, coraçón temeroso, 4) Ay, que sólo os conprehende, 5) Ay, sabroso pensamiento, 6) Ay, peligrosos rreçelos (estrofas zejelescas): $272 \mathrm{v} s$.

84. jAy, cuán dulçe es la mançana, / ay, quán dulçe es, que no agra! // Porfié con mi marido (1): intercalado en la ensalada, núm. 579.

85. ¡Ay!, dulces ojuelos, / no me persigáis, / porque tengo celos / del sol que miráys. // 1) En vn mirar tierno, 2) Quan rrico saliera: $236 \mathrm{r}$.

86. ¡Ay, ojuelos verdes, / ay, los mis ojuelos...!: 65r. (En el Canc. general, Apéndice, núm. 317; en el ms., sólo estrofas 2 y 4 ).

87. - ¡Ay, que el alma se me parte! / -Pecador, epor quién suspiras? / -Dios mío, porque me miras / sin gozarme ni gozarte. // La luz de tu claridad (2): $143 \mathrm{v}$.

88. Bendita Virgen María, / ¿qué teméys, / pues la gracia vos tenéys? // Qué teméys, Virgen sagrada (5): 162r. 
89. Benita, no ay para qué / tú me digas que me quieres, / pues sé que penas y mueres / por otro con mayor fe. // 1) Benita, por muy mejor, 2) Avnque amor no sufre engaño, 3) No cabe en ley de rrazón, 4) Falta es de conocimiento: $245 \mathrm{v} s$.

9o. -Bésame, moça. / -Que ni quiero, ni puedo, ni es cosa. / -Bésame, hermana. / -Que ni quiero, ni puedo, ni e gana. // 1) Y del besar, 2) No lo intereses, 3) Pues me apoca: i94r-v.

91. Bien es que más no desees, / mi deseo, / pues as visto el bien que veo. // Viste quanto deseavas (2): $177 \mathrm{v}$.

92. Bras muere de amores de Ana, / Juana le tira del sayo, / Pelayo por los de Juana / y Ana por los de Pelayo. // 1) Bras dize: -Zagala mía, 2) Si Pelayo te aborresçe, 3) Bien ves que Juana me rruega: 268v $s$. (Cf. 93).

93. Bras muere de amores de Ana... $(=92)$. // 1) Qué maraña y qué primor, 2) De verdad les a tocado, 3) Ana, dime, si quisieres, 4) Cada qual dellos a sido, 5) Y en las quexas que derraman: $63 \mathrm{v} s$.

94. Bras vive ya sin cuydado, / Menga con él biue y muere, / y el zagal menos la quiere / quanto más se siente amado. // 1) Ya está fuera de tormento, 2) Ya siente más el dolor, 3) Menga lamenta su pena: $275^{\mathrm{r}}$.

95. Buen christiano, buen christiano, / no digas que no te aviso... (rromançe del Sacramento): [127 bis]r. (Publicado por Ontañón, p. 189).

96. Caballero, si a Francia ydes, / por Gaiferos preguntad... (romance, con música): 79v. (El texto, en OnTañón, p. 185).

97. Camino lleva María / de dar presto fin de Bras, / porque él va queriendo más / y ella menos cada día. // 1) Verla sin rrazón esenta, 2) Su espacioso fin desea, 3) El camino hecho tiene, 4) Como vn tienpo fue querido, 5) Biue vida tan estrecha, 6) Muere y biue todo junto: $246 \mathrm{v} s$. (Cf. 565 ).

98. Cansado está de oírme el claro río... (octavas): $76 v$ s. (De la Diana de Montemayor, II; p. 66).

99. Cantad cantares santos, / el ánima mía, / que bien se sirve Dios / en alegría. // Cantad cantares tantos (3): 178v s. (Cf. Antol., 107).

100. -Carillo, di, ¿cómo estás / tan triste y disfigurado? / -Temo que siendo apartado / al punto me olvidarás. // 1) Qué dolor te tiene tal, 2) No temo que tu firmeza, 3) Si en ti quedase pintado: 2oor.

101. Carillo, duerme a buen sueño / y discuýdate de ti, / pues tienes cierto de mí / que jamás terné otro dueño. // 1) Duerme y biue discuydado, 2) Nunca seso de quererte, 3) No basta nadie [a] hazer, 4) Entiende sienpre en mirar: [289]v s. (Vuelto a lo divino en 107 y 204).

ıo2. -Carillo, llégate acá. / -Di, qué me quieres, zagal...: 264v. (De MonteMAYOR: Segundo cancionero, $46 \mathrm{v})$.

103. Carillo, Llorente y Menga / se goza y rríe: / cantan "Norabuena venga, / y Dios al mu[n]do lo enbíe". // Con tiple, contra y tenor (4): 172 r. Carillo muere por Menga (mencionado en el 314): cf. 408.

104. -Carillo, pena rrescibo / de conpasión de tu mal. / - ¿Quién no la avrá de vn zagal / que biue como yo biuo? // 1) Qué mal es ése que sientes, 2) Di, tan grave es tu dolor, 3) Qué sientes en mal tan fuerte, 4) Pues tan grande es la ocasión: $247 \mathrm{r}-\mathrm{v}$.

105. -Carillo, ¿quiéresme bien? / -Zagala, sábelo Dios. / -Di como a quién. / -Como a vos. /( 1) Si dixeras como a ti, 2) Pues, carillo, no dirás, 3) No dirás: como a tus ojos: [29o]r.

106. -Carillo, toma plazer, / torna en ti. / - Cómo lo podré hazer, / pues no soy señor de mí? // 1) $O$, quién no fuera, carillo, 2) $Y$ avnque es mal, yo lo busqué, 3) $\mathrm{Y}$ avnque no quiera querer, 4) Cata que estoy espantado, 5) -[Qué t]e hizo, que así pudo, 6) Si es ñudo y con lazada, 7) Carillo, quien te enojó: [298]v s. 
107. Carillo, zuelve oy en ti, / duerme seguro a buen sueño, / sábete que tienes dueño/ que te sacará de aý. // Dueño tienes que a venido (1): intercalado en la ensalada, núm. 579. (Versión a lo divino de 101; cf. 204).

108. Carillo, ya no ay contento, / ya el plazer se me acabó. .: $238 \mathrm{v}$. (En B.N.P., ms. esp. 314, 194v $s$; publicado en P. Laínez, t, 1, pp. 411-412. Sólo la $1^{\text {* }}$ de nuestras dos coplas está en el ms. parisino, que, en cambio, tiene tres más).

109. Carillos, dexá el ganado / y el apero; / veréis dónd'está ençerrado / vn Cordero. // Carillos, dexá el exido (2) (del Sacramento): $42 \mathrm{v}$.

110. Catalina, ¿si soys vos / la que avéys de t[en]er fuerte / conmigo hasta la muerte / como los santos con Dios? // Dizen que el sumo pintor / a pintado vna zagala... (glosa): 53v. (Cf. 111).

111. [Catalina, si sois vos... $(=110)]$. // En el ser glorificado / donde el ser a todos viene... (glosa): $207 \mathrm{v} s$.

112. Clara, lo que meresció / Francisco, a vos no se os niega, / pues que vuestra humilldad llega / donde la suya llegó. // Si Francisco, vuestro santo (6) (en loor de Santa Clara): $185 \mathrm{r}$.

113. Como el sol por vedriera / entra y sale sin rronpella, / nasció Dios de vna donzella, / quedando virgen entera. // Virgen se quedó la madre (3): $169 \mathrm{r}-\mathrm{v}$.

114. ¡Cómo lo canta y meçe / la madre y Virgen pura, / cómo lo canta y meçe / a Dios niño en la cuna! // Adorando está (4): 1 7or-v. (Versión a lo divino de Antol., 317 , o de otra parecida).

115. Cómo no me a de dar pena, / zagales, vna zagala. . .?: 57v. (Casi igual en Canc. Elvas, p. 178).

116. Cómo te va con amores?, / dímelo, amigo y amado. . : [297]r. (De MonTEMAYor, Cancionero 1932, pp. 29-3o).

117. Con el ayre de la sierra / tornéme morena. // 1) Blanca era y colorada, 2) Subióme mi hermosura, 3) Tengo en el siniestro lado, 4) Diga amor lo que quisiere (zéjel): 58 r.

118. Con el rrostro entristecido / y el senblante demudado... (rromançe): $23^{8 r}$. (Publicado por Ontañón, p. 182).

119. Con esas leyes, Silvero, / desengañáos, que n'os quiero. // 1) Çelos son nuestros plazeres, 2) Sin dinero, el amador, 3) En frayles y abades taça, 4) Sabe que an de ser mis puertas, 5) $\mathrm{Si}$ el amante no es valiente, 6) $\mathrm{Ni}$ queráis que ande acosada, 7) Pues nascí con libertad: $235 \mathrm{v} \mathrm{s}$. (Es continua. ción del 531 ).

120. ¿Con qué ojos me miraste, / que tan bien te parescí? / ¿Quién te dixo mal de mí, / que tan presto me olvidaste? // 1) Qué ojos tan sin rrazón, 2) Cómo podiste querer, 3) No fue, cierto, bien fundado: $272 \mathrm{r}$.

121. Con rrazón tienes tú, Bras, / Ios ojos de agua llenos, / pues Menga te quiere menos / quanto tú le (le) quieres más. // 1) No Ilores más sin rrazón, 2) Muestra, Bras, menos pasión, 3) Dirásme, sabio garçón: $275^{\mathrm{r}}$.

122. Con suspiros de dolor / Madalena así dezía: / "No quiero no quiero más alegría, / pues Ilevaron a mi Señor. // Al que ya rresçusitó (3) (de la Rresurrección): $15^{1 \mathrm{r}}$.

123. Con vnas zagalas / de valor preciado / si me vieras, Juan, / jugar al callado. // 1) Saliendo al exido, 2) Hízeles criança, 3) Todas me miraron, 4) Entre ellas estava, 5) Yo por no perder, 6) Galán que suspira: [283]r-v. 124. Contando está Melibeo / a Floricia su dolor. .: 197v. (De GiL Polo, Diana, V; NBAE, t. 7 , pp. $477-478)$.

125. Contentamientos de amor, / que tan cansados Ilegáis. ..: [291]r. (De la Diana de Montemayor, II; p. 72 ).

126. Crecido era mi tormento / en tener muger hermosa; / mayor es mi dis- 
contento: / cáusalo ella ser çelosa. // 1) Más quisiera ser soltero, 2) Plega a Dios que quien desea, 3) Yo soy muy esprimentado, 4) Si en la mesa estoy callando, 5) No tengo de ser señor, 6) Si quitado de pasiones, 7) Si hago del enojado, 8) Dos oras llorando está, 9) Sienpre la hallan llorando, 10) Mill vezes me [a] acontecido, 11 ) Yo querría aconsejar: [286]r-v. (Parece del compilador).

127. Cristóval de Antón Sanches, el de Hita, / queriendo enparentar con Gil Mançano. .. y dixo el desposado "pápate ese hongo" (sic) (Soneto): 280 . ( $\mathrm{Si}$ no es de Padilla, es imitación de los suyos).

128. Cruel pastora mía, / contraria de mi bien y mi contento... que me des de vna ves la muerte o vida (10 liras): $218 \mathrm{v} s$.

129. Cuál es aquella cuytada / que anda tan abatida... (1 copla real) (enigma de la falda): $215^{\mathrm{r}-\mathrm{v}}$.

1 3o. Cuál es la cosa sin vida / que tiene tan gran misterio... (1 copla real) (enigma de el echo): $215 \mathrm{v}$.

131. - ¿Cuál te fue mejor, carillo, / ser pastor o enamorado? / - Más me valió ser amado, / si el amor fuera senzillo. // 1) Qué ganó tu pensamiento, 2) Yo tengo por gran locura, 3) Esa tacha, ten creýdo: 197r.

132. Cuán alta que yba la luna / quando el sol amanecía... (rromançe de Nuestra Señora): [127 bis]r. (Reproducido por ONTAÑón, pp. 188-189).

133. ¡Cuán bien paresçéys, María, / parida del Hijo Dios! / ¡O, divina conpañía, / quán bien paresçéys los dos! // Ved qué cosa tan subida (3): 94v.

134. Cuando Belén se nonbre / paraýso terrena[1]... (rromance): $176 \mathrm{v}$ s. (Lo publica Ontañón, p. 188).

135. Cuando entrardes, caballero, / en el palacio rreal, / no miréis a mí primero, / que dirán que mucho os quiero, / miraréis en general. // 1) Avnque me queráis así, 2) Por fuerça avré de ofenderos, 3) Quando a su tienpo miráis, 4) El miraros no rresisto: $249 \mathrm{v} s$.

136. Cuando Menga quiere a Bras / ya no quiere Bras a Menga: / no verná quando convenga / ventura y amor jamás. // 1) Quando ya Menga quería, 2) Quando Bras tras Menga aballa, 3) Bras vela tras su pasión, 4) Loco Bras en Menga cuyda: 204r. (Cf. 137).

137. Cuando Menga quiere a Bras... (=196). // 1) Quiso Bras a Menga tanto, 2) Llamávala cada ora: 72 r.

138. Cuando sus cabellos Febo / en el mar bañado avía... (rromance): $215 \mathrm{v}$. (Publicado por Ontañón, p. 186).

139. Cuidados, mal me tratáis, / fatigas, no me canséis...: 67v s. (De Diego Hurtado de Mendoza: pp. 364-365; comienza ahí "Cuidados, gran priesa os dais...").

140. Cuidoso va Montesinos, / cuydoso y desconsolado... (rromance): 25 ov $s$. (Puede verse en Ontañón, p. 185).

141. - ¿Cúyo soys, Niño chiquito? / -De mi madre, que es María: / yo soy suyo y ella es mía. // Yo soy suyo, pues me e hecho (3): gor.

142. -Dadme albricias, Gil Pascual, / garrido, dádmelas vos. / - ¿Quién nació? -Vn Niño Dios, / de vna Virgen celestial. // Gil, el ángel me dio nueva (4): $155^{\mathrm{r}-\mathrm{v} \text {. }}$

143. Dama generosa, / Virgen María, / ¡cómo estáys hermosa / de[s]pués de parida! // Cómo estáys hermosa (5): $82 \mathrm{v} s$.

144. Damas, ¿si queréis saber / las mis siete condiciones? / Perequito me llaman a mí, / métenme en casa a los rrenpuxones. // 1) La[s] mis siete condiciones, 2) La segunda condición, 3) Es la condición tercera... etc. (Otras 4 coplas más): $245^{\text {r-v. }}$.

145. Dame acogida en tu hato, / pastora, mi mal te duela...: [297]r-v. (De Montemayor: Segundo cancionero, 71r-72r; ya en Las obras). 
146. -Dame albricias. - ¿De qué, Bras, / de qué, di, pastor, las quieres? / -De que dizen las mugeres / que no an ya de pedir más. // 1) Juan Pastor, a quien las damas, 2) Viendo las damas qu'estavan, 3) Por que el amor no se pierda, 4) Viendo que el amor, de pobre: $233 \mathrm{v}$. (Su continuación es el $5^{80}$ ).

147. Dar tiene amor por oficio / mal pago por buen servicio. // 1) Vna dama a quien quería, 2) Mudó amor, mudó afición: 234v $s$.

148. Dardanio con la punta del cayado... (soneto): 27ov. (Es de RAmírez Pagán: Floresta, t. 2, p. 62; cf. pp. 12-13, 16, 17. Véase también “237 sonnets", ${ }^{\circ}$ 10; $R H i$, 22, 1910, p. 518; RABM, 10, 1904, p. 164;AnM, 3, 1948, p. 83).

149. Dase Dios, Verbo encarnado, / oy por prenda en su partida / en manjar de gracia y vida. // Si amor humano convierte (2): $45^{\mathrm{r}}$.

150. De amor viene vestido / este Zagal; / viene vencido y mortal. // Viene vencido de amor (4): $135^{\mathrm{v}} \mathrm{s}$.

151. De amores está Fileno / mal ferido y mal tratado... (rromançe): $252 \mathrm{v} s$. y (sus últimos 20 vs.) 254v. (En Lucas Rodríguez; cf. Ontañón, p. 192).

152. De aqueste pan de vida / quiero yo comer, / que bien sé la hartura / que tengo de aver. // Dios, que es Rrey del cielo (2) (del Sacramento): 178r.

153. De Belén vengo, pastores, / de ver muy grandes primores. // De Velén vengo admirado ( 5 coplas zejelescas): $157 \mathrm{v}$.

154. De Dios tus amores, / honbre, no desvíes, / mira que no llores / lo que agora rries. // Qué plazer y rriza (6): 171v. (Contrahechura de 159; cf. 614).

155. - ¿De dónde venís, Antón, / alegre y rregozijado? / -Vengo de dexar prendado / por la vista el coraçón. // -Dime quién tal prenda dio (8): $129 \mathrm{v}$ 1 gov. (En el modelo profano del estribillo -glosado por Silvestre, Padilla, Lope de Rueda, etc.-, el segundo verso dice "tan mortal y desmayado").

156. De este pan angelical / en quien veo a Dios por fe, / alma mía, llegá y comé: / sanaréis de todo mal. // Lléguese [e]l alma afligida (2): 44r-v.

157. De este pan gustad, mortales, / con fe y puro coraçón, / qu'es pan de consolación / y sana de todos males. // Llegad con la fe dispierta (3): $43 \mathrm{v} s$.

158. De los cielos soy, / a la tierra vengo, / amores del honbre / bien sé que los tengo. // A la ti[e]rra fueron (3): 141v s. (Versión a lo divino de 9; cf. 8).

159. De los tus amores, / carillo, no fíes. ..: 262r. (Es la versión que da Durán, Cancionero y romancero, Madrid, 1829, p. 148. Cf. 154 y 614).

160. De mi muerte estoy contento, / de mi ventura quexoso, / de mi remedio dudoso, / mas no de mi perdimiento. // 1) Contento y quexoso estoy, 2) Testigo me será Dios, 3) Pues se acortó mi ventura: 234v. (El estribillo es variante de "De mi ventura quexoso...", glosado por Montemayor, Silvestre y otros).

De mi ventura quexoso: cf. 160 .

161. De mirto y de laurel y de mill flores, / en torno del ganado que pacía... sin aver puesto en ella cosa verde (soneto): $226 \mathrm{v}$ y -con variantes- $74 \mathrm{r}$.

162. De Pascuala soy amado, / y Menga ya busca esposo; / en las burlas soy dichoso / y en las veras desdichado. // 1) A Menga sólo me di, 2) Di palabras a la vna, 3) Pascuala me quiere bien, 4) Por qué me quieres dexar: 194r. (Está parcialmente en B.N.P., ms. esp. 314, $212 \mathrm{r}$ : cf. P. LAÍNez, t. 1, p. 431).

163. De una nudosa haya endurecida... (soneto): 269v. (De Ramírez Pagán: Floresta, t. 2, p. 64; anónimo en " 237 sonnets", n $^{\circ} 27$; cf. un soneto de Trillo, con un primer verso análogo, en $B A E$, t. 42, p. 47). 
164. De una Virgen no tocada / naçe Dios / esta noche para nos. // Estava profetizado (5) (al tono de "Asi andavan en Camora"): $165 \mathrm{v} s$.

165. De una Zagala que vi / y vn Zagal que vi con ella / quedé tan fuera de mí, / que a él el alma le di / y el coraçón le di a ella. // Quieres saber, Gil conpadre (2): $4^{\mathrm{IV}} s$.

166. Debaxo de vn aliso rrecostado, / confuso y pensativo está Fileno... y es sólo aquel que muda el pensamiento (soneto): $270 \mathrm{ov}$.

167. Decía vn bachiller a vn su criado: / -Si quieres melón fino y muy gustoso, / haslo de procurar que sea pesado, / tieso de coronilla y oloroso (sólo esto): $75 \mathrm{v}$.

168. Decid, Dios, pues abaxáis / y por amor padeçéis, / ¿quál es la que más queréis? // Vemos vuestra magestad (2): $176 \mathrm{v}$.

169. Decid quién os trae, / mi Dios y señor, / dezid quién os trae / tan preso de amor. // Cómo avéys venido (6): $164 \mathrm{v} \mathrm{s}$.

I7o. -Decid, Virgen madre, / ¿a qué viene Dios? / -Enbíalo el Padre / que pague por vos. // Si el cielo y la tierra (3) (folias): $187^{\mathrm{r}-\mathrm{v}}$. Decidnos, dama: cf. 371 .

171. Decidnos, Sant'Ana, vos, / ¿quién parió al Hijo sin padre...: $18 \mathfrak{y}^{\mathrm{r}}$ y - no completa- 145v. (De Silvestre: $349^{\mathrm{r}-\mathrm{v}}$ y $B A E$, t. 35, p. 315 ; $\sin$ la $1^{\mathrm{a}}$ copla del ms.).

172. Decidnos, Virgen preciosa, / ¿cómo cupo y cabe en vos. .?: $4^{\text {ov }}$ s. (En LÓPEz DE ÚBEDA, Cancionero, $84 \mathrm{v}-85 \mathrm{v}$, y Vergel de flores divinas, Alcalá, $1582,99 \mathrm{v}$; en nuestro ms. faltan las coplas 2 y 4 , pero hay una más).

173. Decidnos, Virgen sagrada, / ¿cómo os fue esta madrugada? // Rresponded, Señora mía ( 7 coplas zejelescas): $159 \mathrm{v}$.

Deja mi mal: cf. 656 .

174. Del Amor se va riendo / vna pulida pastora; / vase del Amor riendo, / y Amor de corrido llora. // 1) Fundada en su gentil ayre, 2) Ser en estremo hermosa, 3) Si en el coro allá en la villa, 4) Enfadado de sus cosas: $240 \mathrm{v} s$.

175. Del cielo baxa vn' estrella / más clara que el claro día. / - ¿Quién la enbía? / -El que tal supo hazella, / y esposa del que la cría. // Dezidme, no fue salida (3) (de la Natividad de Nuestra Señora): $182 \mathrm{v}$.

Descuidado. . .: véase Discuydado

176. Desde aquí los miraremos, / alma, los estremos. // Qué estremo tan estremado (5 coplas zejelescas): 17 or.

177. Desdeñado soy de amor, / guárdeos Dios de tal dolor. ..: [281]r. (De la Diana de Montemayor, II; p. 127).

178. Desenfádame vna Virgen muy perfecta, / que debaxo de los pies tiene la luna... que oýllos, mi fe, Juan, me dan consuelo (6 tercetos): $15^{2 \mathrm{v}} \mathrm{s}$. ("Enfados" a lo divino; cf. 364 ).

179. -Desengáñame, Pascuala: / di, ¿quesísteme algún día? / -Sí, mal aya la zagala/ que de zagales se fía. // i) No puedo creer de ti, 2) Si el amor es cosa ygual: [292]r.

Despierta. .. : véase Dispierta

180. Después de Dios vos sois vno, / gran Baptista soberano, / y después de vos, ninguno / en lo divino y humano. // Después de Dios huno y trino (4) (a S. Juan Baptista): 196r.

181. Después que don Diego Ordoñes / a Pedro Arias muerto avía... (rroman. ce): 23 or-v. (Es continuación de 424. Lo publica Ontañón, p. 183).

182. Después que mal me quesistes, / nunca más [m]e quise bien, / por no querer bien a quien / vos, señora, aborrescistes. // Tan en estremo yndinado, / señora, estoy contra mí... (glosa): 2o $7^{\text {r-v. }}$

183. -Di, Gil, ¿qué piensas hazer / si tu Gila te olvidase? / -Morir, por que 
se acabase / la gloria del padecer. // 1) Gil, pues no ay tan firme estado, 2) Gil, no ves que con la muerte, 3) Dime, Gil, qué gloria tiene, 4) Sesando la causa della, 5) Cómo bives tan seguro: 243r.

184. - Di, Gil, ¿qué sientes de Bras? / - Pascual, está de tal suerte, / que si le dexa la muerte, / será para penar más. // 1) Qué más le puede tener, 2) Es posible que se ofresçe, 3) Bien, pero mientras no viene, 4) Gran fuerça deve de ser, 5) Pues di, por tan gran tropheo, 6) Pues [s]iendo tal su fortuna: 2o1r.

185. -Di, Juan, de qué murió Bras, / tan moço y tan mallogrado... [297]v. (De Montemayor: Segundo cancionero, 66v-67v; ya en Las obras).

186. Dicen qu'el Amor es ciego: / yo no lo niego, yo no lo [niego]. ..: 244 $4^{\mathrm{r}-\mathrm{v}}$. (En B.N.P., ms. esp. 314, 175v, de donde se publicó en P. Lá́nez, t. 1, p. 392; hay 2 coplas más en nuestro $\mathrm{ms}$.).

187. -Dime quién nasció, Pascual, / en aquel portal cercano. / -Bras, nació vn tierno zagal, / Dios del cielo en traje humano. // Mill cantares y clamores (3): 149r-v.

188. -Dinos a dó vas, Pascual, // lleno de tal gazajado. / $-\mathrm{A}$ ver vn bello Zagal / que del cielo a oy llegado. // A dó vas con tanta gala (4): 172v.

189. Dios de vos y vos de Dios, / Virgen, tomastes rrenonbre: / vos de madre y Él de honbre. // Vos tomáis nonbre de madre (4): $46 \mathrm{v}$.

19o. Dios me lo guarde / mi Diego Moreno...: 196r-v. (En Timoneda, Truhanesco, iiij, con una estrofa menos y cuatro más que en el ms.).

191. Dios, $u$ n bien se halla en vos, / y es tal que no tiene nonbre, / que de Dios os hazéis honbre, / y agora soys honbre y Dios. // Sacro Dios, en vos se encier[r]a (2): $84 \mathrm{v}$.

192. Discuydado de cuydado / estava yo. / ¡Ay, triste!, ¿quién me lo dio? // El discuydo que tenía, 2) Sienpre contino contenplo, 3) Sólo fue en mi nascimiento: 273 r.

193. -Dispierta, Juan, por tu fe, / que el dormir te tiene muerto. / -Más me mata estar dispierto. // 1) Nadie, Juan, te a despertado, 2) Sepa yo en este comedio, 3) Dispierta, Juan, con buen brío, 4) Mira mis rrubios cabellos, 5) Mira mis labrios y boca, 6) Mira mis ojos y frente, 7) Dispierta, muévete, leño, 8) Mira bien la rrueca y huso, 9) En fin, dispertar no quieres, 10) Cómo, di, te rredarguyo: [282r-283r].

194. - ¿Dó estás, cuerpo morta[1]? -Alma, ¿qué quieres? / -Que vengas al conbite. - ¿Quién conbida? ...y sabes lo que pierdo si te pierdes (soneto de Sacramento): $224 \mathrm{v}$.

195. Do no ay desamor / no ay mal que lastime. / ¡Ay, coraçón triste!, / ¿cómo bives?, dime. // 1) No llega el sentido, 2) Amor, de qué suerte, 3) No ay fuerça ni anparo, 4) Es tal pensamiento, 5) Dond'este amor prende, 6) Haze con sus mañas: $64 \mathrm{r}$-v.

196. Doncella, a Dios agradáis, / avnque estáis en el aldea: / soys morena y no soys fe[a], / soys castíssima y amáys. // Agradáis al Rrey del cielo (4): $132 v s$. (Versión a lo divino de 646 ; cf. 560 ).

197. Doncella y madre de Dios, / como me miran que os miro / y ven que luego suspiro, / todos piensan qu'es por vos. // Como's ven con tanta gala (3): 4or-v. (Versión a lo divino de "Caballero, andá con Dios, / que como veen que os miro, / no me sienten dar sospiro / que no piensen que es por vos", glosado, entre otros, por P. Laínez y parecido a nuestro núm. 8o).

198. ¿Dónde están tus gallardías, / Mingo, ¿ah?, / que no te aquellotras ya / como solías. // 1) No te veo aquellotrar, 2) Her mill pruevas de prazer, 3) Qués de tu surrón pulido: 202v.

199. ¿Dónde estás, que no te veo, / zagala de mi que[r]er? / ¿Qué's de tu gracia 
y aseo? / ¿Qué haré para te ver? // 1) Por qué te asentas, zagala, 2) Dó te vino tan gran saña, 3) Las zagalas desta villa, 4) No tiene culpa el pastor, 5) $\mathrm{Y}$ pues ves que no ay mudança: $[285] \mathrm{v} s$.

200. - ¿Dónde estás, Señor del cielo? / -En Belén estoy mortal. / - ¿A qué abrigo? -En vn portal, / de noche desnudo al yelo. // Es tan grande tu pobreza (4): $146 \mathrm{r}-\mathrm{v}$.

201. - ¿Dónde vais, Virgen, señora del cielo, / cercada de ángeles alrrededor? / -A ver a mi hijo, mi bien y consuelo, / Dios hecho honbre por ti, pecador. // Vaisos, Señora, mi bien ynmortal (2) (pavana): $179 \mathrm{r}$.

202. - ¿Dónde vas de madrugada, / carillo, con tanto afán? / - Voy al val de Minguillán, / donde está mi enamorada. // 1) Dónde vas con tanta pena, 2) Dime, por tu fe, Pascual, 3) Voy do está todo mi bien, 4) Es más blanca que la plata: [288]r-v.

203. Dos animales groseros / sufrís al rrostro, Señor, / y el sufrir cáusalo amor. // Sobre coros celestiales (2): 141v. (También en GaleAs, 33v, con una copla más).

204. -Duerme, carillo, a buen sueño. / -Gil, ¿si se me va el ganado? / -No hará, que Dios le a dado / otro Pastor y otro dueño. // Bive alegre y sin temor (2): 157r. (Versión a lo divino del 101; cf. 107).

205. Durases, noche, y no viniese el día... (soneto): 271v. (Publicado como de Cetina en sus Obras, núm. 82; anónimo en "237 sonnets", n" 43). El amor de Dios eterno. ... cf. 276 .

206. El amor de Minguilla, ¡huy ha!, / que a mí muerto me tiene, / que a mí muerto me a. // 1) El otro disanto, 2) Saya dominguera, 3) Vella, buen zagal, 4) Yo como esto oyera: $201 v$.

207. El amor piensa que duermo, / y yo me muero. // 1) Ser secreta mi pasión, 2) Piensa que estoy discuydado, 3) Tiéneme la pena tal, 4) Entre mí estoy padeciendo: $248 \mathrm{r}$.

208. El Ciervo viene herido / de la yerva del amor...: 82r-v (De Silvestre:

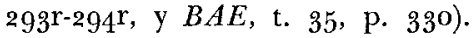

209. El dolor que me destierra / es el que me a de acabar: / ¿Cómo bivirá en la mar / quien dexa el alma en la tierra? // 1) Cómo bivirá el cuytado, 2) Cómo es posible bivir, 3) No puede aver sentimiento: $227 \mathrm{v}$.

2 10. El jüez superior, / de quien se quiere ordenar. .. el jüez y malhechor / y que por tal lo rrecusa (70 coplas reales) (Visita de presos de Cárcel de amor): 208v-214v. (Versión incompleta de la Visita de amor de Gregorio SILVESTRE).

211. El linaje y hermuzura / y la edad $q[u]$ e anbos tenemos. . que mi sobrada afeçión / me llevava ya perdida (1 1 coplas castellanas; diálogo de una monja enamorada con un virtuoso mancebo): $96 \mathrm{r}-\mathrm{v}$.

212. El mesmo Dios verdadero / él se nos da, yo así me lo quiero. // Allá en el cielo sagrado ( 8 coplas zejelescas): $86 \mathrm{v} s$. (Versión a lo divino de "Mi marido es cucharatero, / Dios me lo dio y así me le quiero"; cl. $H D A$, t. 1, p. 64).

213. El Niño qu'está en Belén / por mi bien llora, / llora por mi bien. // Las lágrimas que vertía ( 2 coplas zejelescas): $39 \mathrm{v}$.

214. El pan del cielo venido, / el glorioso maná... (romance con estribillo): $183^{v}$ s. (Publicado por Ontañón, pp. 189-19o).

215. El que en el cielo no cabe / oy en Belén a nascido: / sepamos a qué es venido. // A qué a podido oy el Vero (5): $164 \mathrm{v}$.

216. El que está asentado / con Dios a su diestra / viene aquí ençerrado / y en pan se nos muestra. // Dios que crió el cielo (2) (del Sacramento): 178v.

217. El que tiene amores / con la Soberana / él tendrá favores / y él es el que

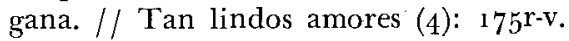


218. El Señor de tierra y cielo / oy tan liberal está / qu'él mismo en manjar se da. // Oy el que tiene poder (3): $44 \mathrm{r}$.

219. El Señor del cielo / nos da (di[o]) vn vngüente (yngüente) / para el padre Adán, / que está doliente. // Viendo Lucifer (6): 171 r-v y $88 \mathrm{r}$.

220. El tu amor, Señora, / oi lo querrás más, / por tu Hijo lo tienes / y hermano nos lo das. // Virgen, tus amores (10): 131v s. (Vuelve a lo divino -como los núms. 613 y 615- el cantar "El tu amor, Juanilla, / no le verás más; / molinero le dejo / en los molinos de Orgaz”, Correas, Arte de la lengua, ed. Alarcos García, p. 455).

221. El Verbo del alto Padre / oy de amor que tiene al honbre / deciende y toma su nonbre, / encarnado en Virgen madre. // A la sacra Virgen pura (3) (de la Encarnación): 48v.

222. En aquel portal / todo derribado / nasçe oy vn Zagal, / señor del ganado. // A poderle ver (4): 91v s.

223. En Belén nasció esta noche / vn Niño de vna donzella / y crióla el Niño a ella. // Alo parido en Belén (5): $162 \mathrm{v}-164 \mathrm{r}$ (el fol. 163 está fuera de lugar; cf. supra, p. 355 , nota 2).

224. En braços de vna Donzella / vi vn Zagal, / que en la tierra no lo ay tal, / y el cielo se espanta della. // El Zagal es nuestro Dios (4): $81 \mathrm{v} s$.

225. En buen ora seáis parida, / Virgen pura y escogida. // Muy ennora buena sea (3 coplas zejelescas): 81r.

226. En el canpo se an topado / la pastora y el pastor, / y el pastor quedó enbovado, / y ella ferida de amor. // 1) Aquesta vista primera, 2) De solamente mirarse, 3) Yva el triste lamentando, 4) Por la selva rresonava, 5) Mill vezes le parescía, 6) Háblanse en vna floresta: $204^{\mathrm{r}-\mathrm{v} \text {. }}$

227. En la corte sin afanes / de nuestro Señor Mexías... cuyo soi (La Pasión. Del Rromano): 1r-16r. (Son las Coplas a la Pasión (1490) del ComendaDOR Román, sin las 19 de Introducción a los Reyes. Va seguida de la Rresurrezión, supra, 7o. Ambos poemas pueden verse en la ed. facs. de A. Pérez Gómez, Valencia, 1955).

228. En la torre de omenaje / donde el gran moro yazía... (rromançe): intercalado en la ensalada 579. (Lo publica OnTañón, pp. 187-188).

229. En las obsequias de Antonio / grande llanto se hazía... (rromançe): $215 \mathrm{v}$. (En Ontañón, p. 184)

23o. En los fríos del ynvierno / vna rrosa floresció: / ¡O, qué flor y fruto dio! // El divino Senbrador (6): $129 \mathrm{v}$.

231. En tal noche (co), gran Princesa, / pues que tal Hijo tenéys, / bien es que nos deis albricias, / bien es que albricias nos deis. // Qué princesa avrá en el mundo (3): $148 \mathrm{v}$.

232. En $u$ n bastón de azevo (zebro) en quien solía... (soneto): 226v y $271 \mathrm{r}$. (Publicado en las Obras de Gutierre de Cetina, t. 1, p. 88; se atribuye a Ramírez Pagán en el ms. 506 de la Bibl. Provinc. de Toledo, 258v; anón. en B.N.M., ms. 2856, 7ov; cf. R. PAGÁn, Floresta, t. 1, p. 16 y $R A B M$, 4 , 1900 , p. $5^{89}$ ).

233. En un pesebre llorando, / rreclinado está vn Pastor, / por silvos suspiros dando: / mirad qué sobra de amor. // Del más supremo collado (2): $85 \mathrm{v} \mathrm{s.}$

234. En $u$ n portal e hallado / vna Pastora tan bella, / que según yo vide en ella, / bien deve guardar ganado. // Vila tan rresplandeciente (2): 133v s.

235. En $u$ na casa vi estar / a muchos cuerpos sin vida... (una copla real; enigma de los hórganos): $215 \mathrm{v}$. (Cf. el enigma "En un sepulcro vi estar", Pliegos poéticos B.N.M., t. 1, p. 302).

Enamoráronse: cf. Namoráronse.

236. Enojada está Minguilla: / cierto no tiene rrazón; / es muger y con pasión: 
/ que lo esté no es maravilla. // 1) Pelayo desesperado, 2) Y viendo que en su querella, 3) Con sus rrazones procura, 4) Harto claro desengaño: 198 r.

237. Es tanto el mal de no verte, / zagala, en lo despoblado, / qu'el silvo que do al ganado / en suspiro se convierte. // 1) El bien de mi entendimiento, 2) Mi rriza sin ti y mi gloria, 3) Quando aquí tu rrostro veo: 242v.

238. Es ventura sin ventura / servir señora cativa; / es tal amar amargura, / amar, amarga dulçura: / vida es muerta y muerte viua. // Es ventura ser amado / si son altos los amores... (Cansión glosada): $279^{\mathrm{r}-\mathrm{v}}$.

239. Esclavo soy, pero cúyo / no lo puedo dezir, no...: 255v. (Es de Baltasar Del Alcázar: Poesias, Madrid 1910, pp. 4-5, y $B A E$, t. 32, p. 414; la copla $3-\mathrm{I}^{\mathrm{a}}$ del ms.-, con notables variantes).

240. Esfuerça y ten confiança, / zagal, y date a plazer, / que en los tiempos ay mudança / y mal fin a de aver. // 1) No duermas en los terrones, 2) No temas a los nublados: $[284] \mathrm{r}$.

241. Espantado estoy, carillo, / quedar virgen quien parió / y ser Dios el que nasció. // No basta el entendimiento (4): 179v s.

242. Espera que desespere / la que a dos amores ama, / por el vno pena y muere / y al otro le rruega y llama. // 1) Cómo se podrán sufrir, 2) Dentro allá en su coraçón: 272 r.

243. Esta noche le dan de mano / al mal villano, / esta noche le dan de mano. // En esta noche preciosa (4 coplas zejelescas): $4^{1 \mathrm{v}}$.

244. Estaba Lucitano rrepastando... (soneto): 74r. (De Montemayor: Cancio. nero 1932, p. 44).

245. Estábase Marfida contenplando... (soneto): $269 \mathrm{v}^{\circ}$. (De Montemayor: Segundo cancionero, 124v; ya en Las obras. Con música en Canc. Medinaceli, $\mathrm{n}^{\circ} 68$ ).

246. Estáis, mi Dios, en el cielo, / en gloria y la gloria dando, / y nascido acá en el suelo, / con penas penas quitando. // Allá en el cielo rreynáis (2): $15^{1 \mathrm{v}}$. (En Galeas, $75^{\mathrm{v}}$ ).

247. Estáse Diego Laýnes / en palacio paseando... (rromance): 7 1r-v. (Publicado por Ontẫón, pp. 181-182).

248. Este divino pan / es el pan que baxó del cielo, / nuestro Dios y nuestro consuelo, / nuestro Rrey y capitán. // El Señor muy poderoso (3): $141 \mathrm{r}$-v.

249. Falso Amor, pues me prendiste, / líbrame de tus cadenas, / que ni quiero ya tus penas, / ni la gloria que me diste. // Ya que estoy en tu poder, / sabe la gloria gozar... (glosa): $247 \mathrm{v} \mathrm{s.}$

250. Fes Deus un misteyro / grande en nosa fe, / fez como cavaleiro, / fes co[mo] quen he. // Ollai que fazaña (11): 172v $s$.

Fílida, pastora mía...: cf. Phílida.

251. Filio de Deus, qu'en Belen / fostes nascido e criado, / sejais muto ben chegado. // En Belen, Señor, nacistes (3): 15ov s.

252. Francisca, si os da pasión / el disfavor que halláis, / es el rremedio, si amáis, / que mudéis la condición. // 1) Biuís, Francisca, con pena, 2) Nunca es vida sosegada, 3) Queréis estrañaros dél, 4) Mudad, si queréis mudança: 241 r.

253. Fueron presos en vn ora / Gil y Gila del amor: / Gil muere por la pastora, / y ella por Gil, el pastor. // 1) Al tienpo que Gil miró, 2) Pudo tanto aqueste ver: $23^{6 \mathrm{v}}$.

254. Fuese nuestro Dios / al sielo a rreynar, / y quedó en la tierra / en este manjar. // Ya el honbre librado (4) (del Sacramento): I81v.

255. Gesto de vieja clueca deshanbrida... (soneto): 75 r. (Atribuido a Diego Hurtado de Mendoza en un ms. de $c a .1585: B R A E$, 1, 1914, p. 45).

256. Gil, si fueres al aldea / y vieres a mi zagala, / dirásle que acá no ay 
gala / que como la suya sea. // 1) Dile, Gil, a mi señora, 2) Gil, si fueres a poblado, 3) Camina, que tu tardança: 268r. (Cf. go8).

257. -Gila, di qués tu yntención. / -Antón, mi yntento es pelar. / - ¿A quién, Gila? -AI que llegar / quisiere a conversación. // 1) Dime qués tu yntento, Gila, 2) Por qué trocar nuestro yntento, 3) Rrazón, Gila, es que te duela, 4) Arrobos tan ynhumanos: 233 r.

258. Gileta se enamoró / burla burlando de vn fraile / y preñada amanesció, / y ella dize qu'es del ayre. // 1) Gileta, como es graciosa, 2) Más hueca que vna canpana, 3) Por ver el mal que tenía: $229 \mathrm{r}$.

259. -Gileta, si al monte fueres, / primero me avisarás. / -Mingo, si bien me quijeres, / yo sé que me buscarás. // 1) Pues dime quándo a de ser, 2) Dime quando pasaré, 3) Yréme lexos de ti: 24or.

260. Gocémonos ya, / pues Dios viene, / y viene y nos da / todo quanto tiene. // Perdió el pecador (4): $134 \mathrm{v} s$.

261. Gran diablo, Leonor, se te a metido / en ese coraçón, que así lo a hecho... con que se alcansará el que arriedro vaya (Soneto con estrambote a doña Leonor de Monsalve, muger de amores): $54 \mathrm{v}$.

262. Gran gasto sería escusado / si en las cortes ordenasen / que las mugeres rrogasen / de quanto les an rrogado. // 1) Gran hazienda que se gasta, 3) Rrezia cosa y gran dolor: 19gr.

269. Gran lástima tengo, Juan, / de ver vn pastor que llora / de amores de vna pastora. // 1) Sobre el cayado de pechos, 2) Díxele por qué quería, 3) De cansado no se mueve: $246 \mathrm{r}$.

264. Gran Señora, gran Señora, / mirad el Niño que llora, / pues qu'es Dios, / y bendita sea la ora / que nascistes él y vos. // Bendita que merecistes (4): 16ov.

265. Gran suavidad y armonía / y melodía; / gustosos pasos de amores, / dulçuras grandes avía / entre la linda María / y el Señor de los señores / por salvar los pecadores. // De los ángeles consuelo (4): 184r-v.

266. -Grande bien nos es venido. / -Dilo, zagal, por tu fe. / -Que la vara de Jesé / esta noche a florescido. // Pára mientes, buen pastor (2): $8_{5}$ r.

267. Guisávalo para el malogrado, / jay dolor, si lo sé guisar!... (romance): 57 r. (Publicado en ONTAÑón, p. 186).

Ha de ser o no a de ser: cf. 35 1.

268. Ha parescido vn Zagal / y vna donzella este día, / que son Jesús y María, / bien de todo nuestro mal. // Siendo Dios muy poderoso (3) (al tono de "La camisa" [¿̨núm. 581?]): 191v.

269. Hasta aquí pudo subir / lo que al cielo y tierra asonbre: / la Virgen virgen parir / y el que nasçe ser Dios-honbre. // Caso de tan gran grandeza $(4): 146 \mathrm{r}$.

270. ¿Hay quien dé posada al Niño / en el suelo? / Qu’él nos la dará en el cielo. // Ay quién quiera aposentar (2 coplas zejelescas): $39 \mathrm{v}$.

271. Hazme, Amor, el mal que puedes, / que según por quien padesco, / y avn Ios males te agradesco. // 1) El bien yo no te lo pido, 2) Por tanto merecimiento, 3) Persigue amor y fatiga: $263 \mathrm{v} s$.

272. $H$ e dado en dárseme poco / por las cosas del amor, / y vame tanto mejor / quanto va de cuerdo a loco. // 1) Yo solía andar perdido, 2) Quando yo en su fuego entrara: 244 r.

279. Hermosa Silvia, si saber deseas / la causa principal de hermosura... de púrpura y de nieve matizadas (8 cuartetos): 256 r-v (Cf. $B R A E, 12,520$ ).

274. Hícele la cama / a mi enamorado, / hízele la cama / sobre mi costado. // A mi Evangelista (6) (A Sant Juan): 48 r.

275. Hijo de mi vida, / mi Dios, no lloréis, / pues sin tener culpa / pena padeçéys. // EI cielo deciende (5): 92r-v. 
276. Hola, que me lleva la ola, / ola, que me lleva la mar... (romance religioso con estribillo): 45v. (Lo publica OnTañón, p. 188).

277. Hoy muestra Dios el secreto / de la carta en que se sella, / sin rronper la nema della. // En la sacra eternidad (4): gor-v.

278. Hoy nasçe Dios en el mundo / y el mundo naçe oy en Dios: / jo, qué

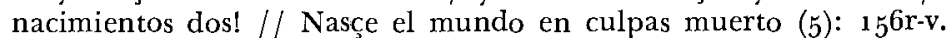

279. Hoy ponen al amor fuego: / fuego a fuego acometió, / y el fuego de amor venció. // Oy por su gran fe y valor (2) (otras de mismo [S. Juan Evangelista]): $140 \mathrm{OV}$.

28o. Huyó, pastores, el mal, / perdióse la suerte mala, / que está Dios hecho zagal / en braços de vna Zagala. // Nunca tales pechos vuo (5): 83v.

281. Inés de mí tan amada, / jay, quién pudiese abraçaros... besos de tal boca dados ( 5 coplas reales): $237 \mathrm{r}$-v.

282. Juan, historiador divino, / ¿quién puede ser más que vos, / pues sois hermano de Dios? // Heredastes el estado (3) (Evangelista): 137v.

283. Juana, mi fe, a lo que siento, / de tu pastor vas burlando: / él está por ti llorando, / y tú dél te estás rriendo. // 1) Él puso en ti su afición, 2) Bien sé que de otro pastor, 3) Dirásme que tu querido: $5^{8 \mathrm{r} \text {. }}$

284. -Juliana, di si quieres / que te guarde tu ganado. / - Mi fe, bien está guardado. // 1) Di, quieres otro pastor, 2) A quien te quiere no quieres, 3) Este surrón y cayada, 4) Hato tan bello y hermoso: [292]v.

285. [La bella malmaridada... = 286]. Qué desventura a venido / por la triste de la bella... 22or-v. (Es, con bastantes variantes, la famosa glosa de Silvestre: 144r-145r).

286. La bella malmaridada, / de las más lindas que vi, / si avéys de tomar amores, / vida, no dexéis [a] mí. // Queriendo mostrar natura / todo su ser en vn ser... (glosa): 223r-v.

287. La dama que a dos amare/ cáygale tal maldición, / que de amor y de aflición / muera por quien la olvidare. // 1) Ninguna más que a vn señor, 2) Muera la que amores tiene: $198 \mathrm{v} s$. (Probablemente, del compilador del ms.).

288. La dama que está en mi pecho / tan estraño su nonbre es, / que dize por el derecho / lo mismo que en el rrevés: / mira el amor lo que a hecho. / (Ana). (Preguntándole a vn galán el nonbre de su dama, dixo): $216 r$.

289. La Donzella y el Garçón / para en vno son. // Nuestro Dios quiere casar (4): $176 \mathrm{r}$.

29o. La gracia perdí, / mas es gran consuelo / que tengo en el suelo / quien pague por mí. // Perdí yo la gracia (4): $88 \mathrm{v} s$.

291. -La gracia que Eva cuytada / por su culpa nos perdió, / di, Bras, ¿cómo es ya cobrada? / -Eso, Gil, pregunto yo. // Di, pues eres avisado (6): $166 \mathrm{r}-\mathrm{v}$.

292. La hermosa y agraciada / tiene gracias más de mili, / y en todo más alindada, / ¿quién es ésa, dime Gil? // De Dios estremada pieça (5) (al tono "De Giralda", o sea del $5_{5}^{2}$ ): $188 \mathrm{v} s$. (Podría ser del compilador).

293. La luz es nascida, / sale el Sol qu'es Dios, / no durmáis, mi vida, / qu'este Sol, mi alma, / nasçe para vos. // Madruga este día (3): $147 \mathrm{v}$.

294. La más santa de las santas / soys, Rreyna del cielo, vos, / pues de millares de tantas / por madre os escogió Dios. // Quien no se puede engañar (3): 8 ov $s$.

295. La misericordia ynmensa, / Juan, tan cerca a Dios os puso... de ser vues-

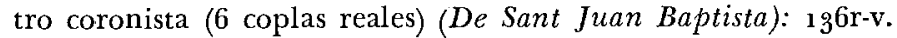

296. La Rreyna del cielo / oy está parida / del Rrey de la vida. // Con gran rregozijo (2): $195^{\mathrm{r}}$. 
297. La Virgen lo halaga: / -Dios niño, ¿qué tenéis? / El Niño le rresponde: / -Lloro por que no lloréis. // Llorava el alegría (5) (al tono de "Madama"): $186 r-v$.

298. La Virgen que entiende y sabe, / Santo Dios, vuestro poder, / es quien puede conosçer / dó abre y cierra vuestra llave. // Quando allá en el santo suelo (2): $84 \mathrm{v} s$.

299. Lágrimas de mi consuelo, / suspiros qu'estáis acá, / solloȩando... que pariste ( 3 coplas de pie quebrado en dobles sextillas): 182 r. (Versión a lo divino de las célebres Lamentaciones de amores de Garci Sánchez de Badajoz).

3oo. Las tristes lágrimas mías / en piedras hazen señal, / y en vos nunca, por mi mal. // Esme tan crudo el amor, / que con pasiones estrañas... (glosa). 208r-v.

301. Lástima es de ver a Bras / cómo gime, canta y llora: 67r-v y -sólo estribillo- $278 \mathrm{v}$. (De Silvestre: 126r-127v; 2 coplas más en el ms.).

302. Leandro en amoroso fuego ardía... (soneto): 73v. (De Montemayor: Las obras, 27r; Segundo cancionero, 122v).

303. Levantóse el alma mía, / contenplando en sí quien era... de virtudes muy labrada (4 redondillas): $149 \mathrm{v}$.

304. Libres alçé mis ojos, / señora, quando os miré... 203v. (Es, con dos coplas menos, la versión de Flor de enamorados, 25v-26v).

305. Lindas son rrosas y flores: / más lindos son mis amores. // Hermosas son las estrellas (4 coplas zejelescas): $154 \mathrm{v}$.

306. Los ojos que dan enojos / por ver y mirar con ellos / más valiera no tene(e)llos. // 1) Ay, ojos desesperados, 2) Como rreciben contento: 254r.

307. Los ojos que de rrendón / luego en viendo quieren bien / no vean, porque si ven, / jay del triste coraçón! // 1) Es esperiencia vulgar, 2) Deseo, amor y avaricia: 23 ir y -sólo estribillo- $229 \mathrm{v}$.

308. Los que estáis en el aldea / le diréis a mi Zagala / que el cielo no tiene gala / que como la suya sea. // Dezí que porque se umilla (2): $129 \mathrm{r}-\mathrm{v}$. (Versión a lo divino de 256; probablemente del compilador).

309. Los santos gloriosos, / tu humildad mirando, / te están oy loando. // Loan los favores (3) (al tono de "Ojuelos graciosos", o sea del 387): $185 \mathrm{v}$ s.

310. Luego fuera yo pastor, / siendo de aquesta manera, / con tal condición que fuese / yo cabrero y vos cabrera. // 1) Las cabras avían de ser, 2) Y que fuese sin pasión, 3) Y que fuese el pedernal, 4) $\mathrm{Y}$ al tienpo de hazer quesos: 7 ov.

311. Llaman a la puerta, / y espero yo a mi amor; / que todas las aldabadas / me dan en el coraçón. // Prometióme de venir (1): intercalado en la ensalada, núm. 579 .

312. Llenos de alegría santa, / pronunciemos este día...: 182v $s$. (De Silvestre: $349 \mathrm{v}-35$ ov, y $B A E$, t. 35 , p. 315).

313. Llevadnos adonde vais, / Rreyna y señora del cielo, / no nos dexéis en el suelo. // Quedamos sin alegría (2): 179r.

314. Llora Dios el mal del honbre / y él se rrie: / ¿quién avrá que fíe del honbre, / quién avrá que del honbre fíe? // Hallóse en su juventud (7) (Al tono "Carillo muere por Menga y Menga rrie", o sea del 408): 8or.

315. Lloraba Gonçalo Bustos / allá en Córdova la llana... (rromançe): $250 v$. (Publicado por Ontañón, p. 181).

316. Llorad, damas, sin cesar, / todas con galán concierto, / por Amor, que disque es muerto. // 1) Por que más os comováis, 2) Ved qué desgracia tamaña, 3) Con los ojos le tiró: 199v.

317. Llorando estava la Cava / con gran dolor que tenia... (rromançe): $278 \mathrm{v}$. (Publicado por OnTaÑón, p. 181). 
318. Llorando, mi Rredentor, / dais al honbre gran consuelo. / ¿Qué hará quando en el cielo / te goze como a Señor? // Tu congoxa desabrida $(6): 186 \mathrm{v} s$.

Madama...: cf. 297.

319. Madre, [a] aquel Moçuelo / del camisón labrado / luego se lo vide / que andava enamorado. // Madre, aquel Moçuelo (3): 15ov. (Cf. 4o).

320. Mal desdén a mí me mate / si es posible que otro tenga / más amor ni fe con Menga. // 1) Cáygame tal maldición, 2) Con ansia y rravia mortal: $56 \mathrm{v}$.

321. Mal haya quien mal os quiere; / vos, señora, dezí amén, / que yo lo diré tanbién. // 1) Quán de mal conocimiento, 2) Quien esos graciosos ojos, 3) Quién podrá dexar de veros: $24 \mathrm{ov}$.

322. -Maria, ¿̇i qué harás / quando a Dios ayas parido? / -Servirlo y quererlo más / que en mi vida lo e querido. // Si Dios por madre te quiere (3): 186v. (Versión a lo divino de 643).

323. María, dulçe esposa del muy alto, / del gozo que parida dais al suelo / avéis rregozijado todo el cielo. // Mortal con desnudés y en el ynvierno (2): 142v s. (En Galeas, 34v).

324. María mata a Silvano, / y hazelle que no muera / no puede, ni avnque quisiera, / no puede ni es en su mano. // 1) El trizte Silvano muere, 2) Él muere y su mal no alcança, 3) Lo que más s'espera della: 6iv.

325. María parió vn Zagal / de tantas virtudes lleno, / que en el suelo no lo ai tal, / ni allá en el cielo más bueno. // No se pueden conparar (2): $85 \mathrm{r}$.

326. Marido, ¿̨si queréis algo? / que me quiero levantar. // 1) Marido, después que os trato, 2) Púseme anoche galana, 3) De la cama estoy cansada: 243v. (Cf. 444).

327. Más valiera no miraros, / pues en mirándós perdi / todo el bien que en viéndôs vi. // 1) Como en burlas començé, 2) A mí me hizo perder, 3) Perdí por tan bien miraros, 4) Si yo no pensara amar, 5) No pensé que siendo humana, 6) Pluguiera a Dios que n'os viera: $205^{\mathrm{r}-\mathrm{v}}$.

328. Melindres en muger fea / ningún christiano los vea. // 1) Vn melindre desabrido, 2) Avnque la lengua lo calla, 3) Nos atosiga vn rregalo, 4) Para feas no nasció: $236 \mathrm{v} s$.

329. Menga a Gil no satisfaze, / y Gil no siente dolor, / porque lo que el amor haze / lo deshaze el desamor. // 1) Quando Menga a Gil amava, 2) No viendo señal alguna, 3) Gil a Menga entiende bien: $56 \mathrm{v} s$.

330. Mi alma de amores congoxada, / vencida del furor de mi tormento... ( 2 octavas sobre el pie "Sola Francisca es causa de mi pena") (A Francisca): $54 \mathrm{r}$.

331. Mi fe, Gila, del tu medio / no me curo, / qu'el morir es el rremedio / más seguro. // 1) Olbidar no es cosa cierta, 2) Escucha, Gil, y verás, 3) No la olbidaré, pastor: $6 \mathrm{gr}$.

332. Mientras que el morieo duerme, / vida y vámonos, amor. // 1) En tanto que está afloxando, 2) Tiénese por conclusión, 3) En el suseso no ay duda: $63^{r}$.

333. -Mingo, olvida esa donzella. / - ¿Por qué, [d]i? / -Porque tú mueres por ella, / y ella se burla de ti. // 1) Tú mueres por sus amores, 2) Hasta agora no e sentido: [288]v $s$.

334. Morenica, no desprecies / tu color morena, / que aquésa es la color buena. // 1) La blanca de natural, 2) Dime, a Dios qué le costava: 59 r.

335. Moriré de amores, / moriré. // Moriré de amores (4): 94v. (Cf. 336).

336. Moriré, moriré, / jay, que yo moriré! // Gozo de los cielos (5 cuartetas encadenadas): $39^{\text {r. }}$ (Cf. 335). 
337. -Muero de amores, carilla, / ¿qué haré? / -Que te mueras, a la fe. // 1) Carilla, si del amor, 2) No ay rremedio menos fuerte, 3) Carilla, para bivir, 4) Como en fin de mis cuydados: $263 \mathrm{r}$.

338. Nace Dios en vn pesebre, / y avnque pobre y viejo [sic por baxo] está, / a (a) los rreyes lunbre da. // Desnudo y pobre llorando (2): 147v. (En GaLeAs, 63r).

339. Nadie con muger pretenda / contienda muy porfiosa, / mayormente si es hermosa. // 1) Tienen mando sobre todo, 2) No ay honbre que las rresista, 3) Quien con ellas prende rruydo, 4) Tienen formas singulares, 5) Házennos bivir alerta, 5) Ella es guerra a sangre y fuego: 199v $s$.

340. Nadie no diga, / que de vn fraile e de ser amiga; / no diga nadie, / que e de ser amiga de vn fraile. // 1) Honbre soltero, 2) Estos mocillos, 3) Estos mocetes, 4) Frayle lo quiero, 5) Bueno es abad, 6) Frayle rricacho (incompleta): $244 \mathrm{v} s$. (Parece ser del compilador).

341. Namoráronse María / y el Hi de Dios padre, jalıé!, / bien enamora(n)ronsé. // Oteó Dios la Zagala (4): 129r. (Versión a lo divino de: "Namoráronse mis ojos / de vuestra hermosura, jahé!, / mal enamoraronsé”, Timoneda (?), Aurelia, III).

342. Negóme Marina / la fe que me diera, / y salióse afuera. // 1) En tiniebla oscura, 2) Devió de ser juego, 3) Si estuve en la cunbre: $232 \mathrm{v}$.

349. Ningún honbre mayor hijo / tuvo en todos nuestros días / como el viejo Zacarias. // Fueste bien aventurado (4) (de San Juan): 177v $s$.

344. Niña por quien yo suspiro, / duélante ya mis enojos. . .: 236v. (Está en B.N.P., ms. 314, $211 \mathrm{r}-\mathrm{v}$; impresa en P. LAínez, t. 1, pp. 430 s.; hay en nuestro ms. dos coplas menos y una más que en el parisino).

345. Niño de rreyes servido: / iquién tal vido! // No ay coraçón que no quiebre (2 coplas zejelescas): $143 \mathrm{v}$.

346. Niño Dios, dezid ¿qué avéis, / qu'estáis tenblando de frío? / Pues más os queda, Dios mío, / que de amores moriréis. // El amor os hizo ser (3): 161 r-v.

347. Niño Dios nascido al yelo, / troquemos rropa los dos: / tomá mis trabajos vos, / yo tomaré vuestro cielo. // Estad vos con vuestra madre (1): 147r.

348. Niño Dios, que estáis llorando / y solloçando, / ¿qué tenéys, qué avéys, Señor, / que estáis tenblando? // Siendo vos el Rrey del cielo (5): 164r.

349. Niño tal y en vn portal, / iquién vido tal! // Niño tal tan afligido (1; zéjel): 182 .

35. No cuydé que entre pastores / el amor dava dolor... (romance): 264 $4^{\text {r-v. }}$ (Publicado por Ontañón, p. 186).

351. No culpes mi pensamiento, / señora, por lo que quiso... (1 copla real sobre el pie " $A$ de ser o no a de ser"): $54 \mathrm{r}$.

352. No denotan esperança / los ojos verdes que vi, / pues son negros para mí. // 1) La color más celebrada, 2) Verdes [s]erán vuestros ojos, 3) Dan esperança de muerte, 4) Gloria rresçebí en miraros: $241 v$.

353. No desesperes, carillo, / esfuérçate y ten confiança...: 81v. (De Silvestre:

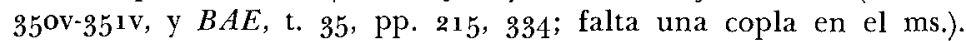

354. - No estés, Pedro, de tal suerte, / esfuerça, ten confiança. / -Ay, que la mesma esperança / es la causa de mi muerte. // 1) El mal de amor, conpañero, 2) Pues cómo esperas sanar: $221 \mathrm{v}$.

355. No estés tan contenta, Juana, / de averme tratado así, / mira que lo que oy por mí / podrá ser por ti mañana. // 1) Si piensas por aventura, 2) El tratarme de tal suerte: [284]r. (CF. 356).

356. No estés tan contenta, Juana, / ni alegre de verme así, / mira que... $(=355)$. // 1) Todo mi hato cabrio, 2) Ya sabes que por tu amor, 3) Quando estás entre pastores: $65 \mathrm{r}$. 
357. No fíes, Gil, de pastora, / y si fiares de alguna. . . 68v s. (De Silvestre: 124r-126r, con 9 coplas, como en el ms., 3 de ellas diferentes).

358. No hay alguna estrella, no, / como la Madre y donzella: / [qu']el mismo Sol naçe d'ella. // Su lus, el Sol prefulgente (3): $41 \mathrm{r}$.

359. No hay más que ver que miramos, / Niño, en vos, / pues vemos honbre, y soys Dios. // En ese portal do estáys (4): $89 \mathrm{v} s$.

36o. No más ya, mi zagal, linpia tus ojos / de aquel triste licor con que los bañas. . si penas tú por mí, yo por ti muero (soneto): $227 \mathrm{r}$.

361. No me quexo del amor, / qu'el amor contento dexa: / del desamor es mi quexa (sólo eso): 199r.

362. No miráys si no matáis, / porque cada ves que veys / nunca los ojos bolvéys / sin que mill almas rrindáis. // I) Tal veneno está ençerrado, 2) Los ojos son amorosos: 241v s.

No muestra en sus concetos. . . cf. 471 .

363. No os duela, mi madre, / esto que diré: / mal de amores é. // No siendo querido (6): 88v. (Versión a lo divino de Antol., 122).

364. No os paresca, señor, a maravilla / el averme venido [a] aquesta aldea, / huyendo d'esa loca de Sevilla... y hiédele la boca más qu'el culo (29 tercetos) (Enfados): $217 \mathrm{v} \mathrm{s.} \mathrm{(Cf.} 178$ ).

365. No quieren ser de oro, no, / señora, vuestros cabellos, / qu'el oro quiere ser d'ellos. // I) Huyen sienpre la ocasión, 2) Tuvo el oro diferencia, 3) Prende el amor alma y seso: $242 \mathrm{r}$.

366. No se hizieron, Pascuala, / los plazeres para mí. .: 216r. (En Flor 1578 , pp. 200-202, con las coplas i y 2 del ms. y sin la 3 ).

367. No se vio ventura / que tan alta fuese / que a su Dios comiese / su misma criatura. // A seguro puert[o] (3): 148r.

$3^{68}$. No so yo quien veis biuir, / no, no, no...: [296]v s. (De Montemayor, Las obras, $19 \mathrm{r}-\mathrm{v}$ ).

369. No te govierna rrazón, / Amor, todo eres antojos, / pues la culpa es de los ojos / y págalo el coraçón. // i) Por qué, Amor, con tus rrigores, 2) Si los ojos delinquieron: $233^{\mathrm{r}}$.

37o. No tengas ya confiança, / Galatea, en tu pastor, / porque no cunple el amor / lo que promete esperança. // 1) Teme, pastora, tu daño, 2) Tu alma no se rresuma, 3) Bras, pudiérate culpar, 4) Desengánate de hecho: $263 \mathrm{v}$.

371. ¿No viste, Bras, la parida, / por tu vida? / ¿No viste, Bras, la parida? // La que a parido este día ( 5 coplas zejelescas) (al tono de "Dezidnos, dama"): $189 \mathrm{v}$.

372. Norabuena estéis, Prinsesa, / bien donde el bien se atesora, / Señora, estéis en buen ora. // Virgen, norabuena estéis (4): $181 \mathrm{r}$.

373. Nuevo esfuerço y nuevo aliento, / señor tio es menester... ydos que ya turbamulta / . . contra me (71/2 coplas reales) (El conde Claros): $214 \mathrm{v} s$.

374. Nunca pudiste, Cupido, / meter guerra donde ay pas. .. 66r. (De SiLVESTRE: 119r-12or, con una copla menos y una más).

375. O, alma endurecida, / conviértete a tu Dios omnipotente... al paraýso çeleste y muy divino (4 liras) (baxa lira): $47 \mathrm{v}$.

376 . O, carnero muy manso, o, buey hermoso... (sólo el primer cuarteto, tachado, del soneto a vn cornudo): $75 \mathrm{v}$. (E1 soneto es de Diego Hurtado de Mendoza: p. 26).

377. O, dulçe suspiro mío, / no querría dicha más... 66v $s$. (De Silvestre: 104r$105 \mathrm{r}$, con I copla más).

O, qué grande conbite: cf. $7^{8}$.

378. ¡O, qué noche de alegría / y más que el dia! // Noche bienaventurada (4, zéjel): 17 ir. 
379. ¡O, qué venteziño / anda en aquel balle! / Déxame, carillejo, / yr a buscalle. // Levantóse vn vento (4): 4or.

380. ¡O, si saliese ya del alma mía / la tiniebla de la culpa del pecado!, / verás quán gran bien es Dios humanado. // Podrá mirar y ver al Sol de lleno (2): 139 r.

381. ¡O, Virgen madre y Señora, / tu Dios y Hijo y Señor / que tan dulce llora / sí que lo a de amor! // Rredentor precioso (3) (chançoneta): $38 \mathrm{v}$. 382. ¡O, Virgen muy pura!, / ser Dios hambre hecho / es onrra y provecho / que eçede a natura. // No suele caber (2): 15 or.

383. O, vos, preciosa lira, que vais a ser de Dios dulçe ynstrumento... de polvo y sangre y de sudor teñido (3 liras): $144^{\mathrm{r}}$.

384. Ojo a la fe, pecador, / que aqueste pobre portal / es la corte çelestial. // No pueden divisar (7): $168 \mathrm{v} s$.

385 . Ojos tristes, no lloréis, / y si llorardes, pensad...: [292]v. (De la Diana de Montemayor, I; pp. 60-61).

386. Ojuelos graciosos, / que os estáys rriendo / de verme muriendo, / de verme muriendo. // 1) Prometéis favores, 2) Vais rregozijados, 3) Veysme lastimada: 268r. (Cf. $3^{87}$ ).

387 . Ojuelos graciosos / que os estáys rriendo / del que está muriendo. // 1) Ojos que matáys, 2) Ojos más traydores, 3) $\mathrm{Y}$ si veis tormentos: $201 \mathrm{v}$. (Cf. núms. 309, 386, 6o9, 610).

388. -Olvida, Bras, a Benita, / pues que te dexa y se va. / - iAy, mi Dios!, y quién podrá / olvidalla, qu'es bonita. // 1) Mira qu'es desamorada, 2) Aquel meneo y cantar, 3) No te vença, Bras, amor: $243^{\mathrm{r}-\mathrm{v}}$.

389. Olvidástesme, señora: / mucho más os quiero agora. ..: [281] $\mathrm{r}$ (De la Diana de Montemayor, II; p. 128 ).

390. ¿Para qué nacéys llorando, / nuestra alegría? / ¿Para qué nacéys llorando? // Aquese precioso lloro (3 coplas zejelescas): $92 \mathrm{v}$.

391. ¿Para qué os adereçáis, / dezí, pelleja çurrada?, / pues que de vieja no estáis / para estar amançebada. // 1) $Y$ para qué os conponéys, 2) Las galas, guantes y olores, 3) Dízenme que soys abismo, 4) Si pretendéys cosa nueva, 5) No siento gala que os cuadre, 6) Conprad, vieja, vn ataúd: 252r-v.

392. Para vos se hizo la fiesta, / alma escogida, / para vos se hizo la fiesta, / para que tengáis vida. // Hizo fiesta aquel cordero (3) (de Sacramento): $145^{\mathrm{r} \cdot \mathrm{v}}$

393. - Pardalio, Amor te busca. - ¿Y qué me quiere? / -Que buelvas a querer a Calatea... y aver jamás amor yo te lo juro (soneto): $74 \mathrm{v}$.

394. Paresçéys, Virgen presiosa, / con Hijo qu'es lus divina, / el Hijo, flor de la rrosa / y vos la rrosa d'espina. // A rrosa soys conparada (2): $181 \mathrm{r}$.

395. Parida vi vna Donzella / tal que juro por mi fe / qu'es la más linda y más bella / que será ni nunca fue. // Mientras que la bella esposa (2): $86 \mathrm{r}$.

396. Pasados contentamientos, / ¿qué queréys?..: [293]r. (De la Diana de MonTEMAyor, VI; pp. 270-271).

397. - Pascuala, ¿no me dirás / dó parió aquella Zagala? / Y rrespóndele Pascuala: / -Ve a Belén y verlo as. // Sube por aquella sierra (5): 168v.

398. Pastor, avnque ves que son / dos cuerpos Alcida y Bras, / no quieren ni tienen más / que vn alma y vn coraçón. // 1) Amor, qu'es bien de las gentes, 2)..., 3) Su unión es tan vnida, 4) En dos vnión tan estraña: 23ıv s. (Probablemente las estrofas son del compilador; de 1 sólo se da el comienzo, de 2 sólo la vuelta. Cf. 399).

399. [Pastor, avnque ves que son... (=398)]. El que no vido y creyó / de glorias de amor se vista... (glosa): $232 \mathrm{r}$. 
40o. Pastor del cielo enbiado, / nuestra carne avéys vestido, / que vengáis y humanéys / y seáis en buen ora venido. // Venistes, Señor, del cielo (2): 81 .

401. Pastora cuya ventura / Dios quiera que sea tal... (coplas castellanas) (otras de Diana): [291r-292r]. (De la Diana de Montemayor, III; pp. 139145; faltan en el ms. las 9 últimas coplas).

402. -Pastora que andas en sierra, / ¿cómo te va con amar? / -Antes me trague la tierra / que bolverme a enamorar. // 1) Siendo ninfa, era preciada, 2) Agora que estoy soltera, 3) A pastores confiados, 4) Quiero cantar a plazer: $267 \mathrm{v}$.

403. Pastorcico, ¿por qué lloras, / estando rrezi[é]n nascido? / Dime si amor te a ferido. // Tu soberana cabaña (2): $13^{8 \mathrm{v}} s$.

404. Pastores, baxá a la sierra, / vení, veris vn Zagal, / qu'el mayor bien de la tierra / no y(a)guala a bien de su mal. // Vení, veréis vn Pastor (2): 59 r.

405. Pastores, doyos por nuevas / que tenemos en la villa...: 42r. (En LóPEz DE U BEDA: Cancionero, $17 \mathrm{v}$ s., y BAE, t. 35, p. 209).

406. Pastores, venid a ver / vn Zagal que, de oy nascido, / nasçe de amores ferido. // Desde que el Zagal salió (3; zéjel): 14 Iv.

407. Pelayo muere por Juana, / y Juana muere por Bras, / y este Bras muere por Ana, / y Pelayo mucho más. // 1) Pelayo por Juana muere, 2) Está Juana padeciendo, 3) Llora Bras su desventura, 4) Ana se quexa llorando: 219v.

408. Pelayo muere por Menga, / y Menga rrie: / ¿quién avrá que fie en Menga, / quién avrá que en Menga fíe? // 1) Solía Menga querello, 2) Si Pelayo adolecía, 3) Pelayo se sostenía, 4) Solía de quando en quando, 5) $\mathrm{Pe}$ layo se está muriendo: [284]v. (Cf. 314).

409. Pensamientos, ¿̇ónde vais?, / mirad que os despeñaréis...: 25or-v. (De Diego Hurtado de Mendoza: pp. 421-422; figura también en Canc. Elvas, pp. 174-175).

410. [P]hílida (?), pastora mía, / que me parto yo sin ti; / jay que no, mas ay que sí! // 1) O, si del mundo partiese, 2) Perdóname si codicio, 3) No son çelos por pensar, 4) Mas si sospechas, zagala, 5) Por librarme en tal estrecho, 6) Has, zagala, este concierto, 7) Como si en tu mano fuese, 8) Si en algo grato te soy, 9) Dilo, siquiera burlando: $275 \mathrm{v} s$. Pisuerga caudaloso...: véase 414 .

411. Plazeres, bien podéis yros, / qu'el lugar do avéis d'estar / todo lo tiene el pesar. /( 1) Plazeres, buscad a quien, 2) Avnque yo quiera ospedaros, 3) Plazeres, tarde venidos, 4) Plazeres, Dios es testigo, 5) Plazeres, tuestes llamados: $198 \mathrm{v}$.

412. Plega a Dios que si yo creo / que ay otro bien sino vos... señora, si os olvidare (10 redondillas): 52v. (Parece haber gozado de gran popularidad hasta entrado el siglo xvir. Se la atribuye el curioso fÑ $1 G U E Z$ DE Medrano en su Silva curiosa [1589], París, 16008, pp. 94-95; figura en el Ramillete de Flores, $4^{\text {a }}$ pte., Lisboa, 1593 , de donde pasó a la Sexta parte de la Flor de romances nuevos, Toledo, 1594 , y con ella al Romancero general de 160o; en su edición moderna de éste, p. xü, González Palencia la atribuye a Juan Salinas y Castro [!]. Se incluyó después en la Segunda parte de la Primavera y flor de los mejores romances [1629]).

413. Pluguiera a Dios que no fueras / de mis ojos conocida. // Asme costado tan cara, / después que te conocí... (glosa): 221 r.

414. [Pluguiera a Dios que nunca yo naciera, / o ya que al fin nascí, que nunca amara, / o ya que amé, en partes me enpleara / a do mi amor agradecido fuera]. Pisuerga caudaloso, / que en la famosa Pincia es tu rribera... (4 liras) (Glosa a la prinsesa de Lerma): $5^{6 \mathrm{r}}$. 
415. Pode quien tuviere viñas, / ponga majuelo cadaño... ni favor que ayáis tenido ( 12 coplas reales): $216 \mathrm{v} s$. (Son las "Coplas en vituperio de la vida de palacio y alabanza de aldea hechas por Gallegos, Secretario del Duque de Feria", que publicó Morel-Fatio en $B H i, 3,1901,31-34$. Nuestra versión carece de la última copla y contiene variantes de interés. Gallardo, Ensayo, t. 1 , cois. $88-89$ publica una versión mucho más breve, de un ms. en que el poema se atribuye a Baltasar del Alcázar; por eso se publicó entre las Poesias de éste en la ed. de Sevilla, 1878).

416. Por Antequera suspira / el Rrey Chico de Granada... (rromance): 25 ov y (música, con sólo 4 vs.) $77 \mathrm{r}$. (Véase OnTañón, p. 191).

417. Por aquí, por allá / el Hijo de Dios está. // Por aquí me busca y llama (3): $114 \mathrm{v}$.

418. Por bien del ganado / baxó el buen Pastor: / éste sí es amor / que Dios nos a dado. // El Pastor divino (3): $157 \mathrm{r}$.

419. Por divina operación / vna Zagala a parido / vn Zagal, el más garrido / de quantos fueron y son. // Es María la Zagala (4): 82r.

420. Por este pan qu'en el suelo / Dios enbía / va corien[d]o hasta el cielo / el alma mía. // Para ver a Dios acá (2): $43^{\text {r-v. }}$

421. Por gloria de vuestro nonbre / y grande bien para nos, / baxáis, Dios, de Dios al honbre, / y al honbre subís a Dios. // En la carne Dios nasciendo (2): 142r. (En GaleAs, 24r-v, con una estrofa más).

422. Por haverme amor llagado, / de vos me siento corrido... (1 copla real) (A una señora a quien servian muchos): $220 \mathrm{v}$.

423. Por la culpa paternal / nasçe Dios oy en B[e]lén: / bienaventurado mal / que fue causa de tal bien. // Bienaventurada culpa (3): 93r.

424. Por la puerta de Çamora / sale Pedro Arias armado... (rromançe): 23 or. (Lo publica Ontañón, pp. 182-18g).

425. Por las culpas, pecadores, / pues a Dios veis suspirar, / suspiros avéis de dar. // El que vuestras culpas mira (3): 39 r-v.

426. Por las rriberas de Fúcar / va Niso con su ganado. . (rromance): 249r. (En Lucas Rodríguez; cf. Ontañón, p. 191).

427. Por los más espesos montes / y lugares de Navarra... (romance): $257 \mathrm{v} \mathrm{s.}$ (En Ontañón, pp. 190-191).

428. - ¿Por qué dexas, Gila, [a] Antón, / pues por ti tan rroto queda? / -Porque acabó su moneda, / acabé conversación. // 1) A cabo de tantos años, 2) No te acuerdas que primero, 3) Luego mal le querrás dar: $297 \mathrm{v}$.

429. - ¿Por qué no esperas, Ana? -Tengo miedo... (5 sextetos-lira): 228r-v. (Está en el Cancionero de Juromenha, con algunas diferencias: $Z R P h, 8$, 1884 , pp. $59^{8-599)}$.

430. - ¿Por quién suspiraste agora, / dime, pulido zagal? / -Por la más linda pastora / que ay en todo mi lugar. // 1) E de verte gran dolor, 2) Véome tan lastimado, 3) Di por quál rrazón, carillo: [294]r.

431. - ¿Por quién venís, mi Dios, hasta la tierra? / -Estoy de amor del honbre tan vencido... La vida quiero dar por su pecado (4 tercetos) (Colloquio): 143r. (En Galeas, 39r, con tres versos más).

432. Por tan alta vía os dais / en este manjar, mi Dios, / que sin perder de quien soys, / vos en el honbre quedáis / y el honbre se queda en vos. // Dase vuestra magestad (2) (del Sacramento): $178 \mathrm{r}-\mathrm{v}$.

433. Por tan alto os tiene el mundo, / que conviene, Juan, que vos / les digáis que no sois Dios. // Como vuestra luz crecía (2): 148 r.

434. Por ti, zagala, estoy tal, / que ternía por contento / entrar en tu pensamiento / para bien o para mal. // 1) Estoy para contentarme, 2) No puede aver suerte mala, 3) Para mal: no sé yo quien: 6gv s. (Estribillo y $3^{\text {a }}$ copla en Silvestre, $128 \mathrm{v}$ s.). 
435. Por tu fe, Clemente, / si vas al exido, / mira que veas / vn grande Señor, / que siendo mi Dios, / en carne a nascido. // Al Rrey soberano (2): 135v.

436. Por $u$ n verde prado / de fresca sonbra y llen[o] de mill flores... de verse así apartado de su ninpha hermosa (9 sextetos-lira; pero hexasílabos en

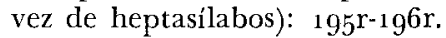

437. Por unos dos negros ojos / que miré / me an nascido mill enojos / sin porqué. // 1) Por vnos negros ojuelos, 2) Yo no sé si va en mi suerte, 3) $\mathrm{Si}$ es porque sois poderosos: $196 \mathrm{r}$.

438. Porque quesistes os vimos, / sacro Dios: si esto no fuera, / nadie veros meresciera. // Por querer vuestro querer (4): $91 \mathrm{r}$.

439. Porque te besé, carillo, / me rriñó mi madre a mí: / torna el beso que te di. // Carillo, buen amador, / descanso, vida y mi gloria... (glosa): [283]r.

440. Preciosí[si]ma Donzella, / pues el Sol eterno es Dios, / ¿cómo nasçe de vn' estrella / tan humillde como vos? // Siendo Dios tan sin medida (2): $198 \mathrm{v}$. (En Galeas, 4or).

441. Preso llevan al caballero, / ¡ay Dios!, ¿si le soltarán? // Preso llevan a vn amante (1): intercalado en la ensalada, núm. 579.

442. Prevenid pañales, Virgen, / al Niño que a de naçer, / pues previno él vuestro ser. // Mientra que rreposa el Niño (7): $128 \mathrm{r}-\mathrm{v}$.

443. Prinseza del sacro ynperio, / soberana enperadora, / bien seáys parida agora. // Bien, pues que vos bien paristes (4): gov.

444. Pues con vos tan poco valgo, / y sienpre os e de rrogar, / ved, marido, si queréis algo, / que me quiero levantar. // 2) D'espoladas os e dado,

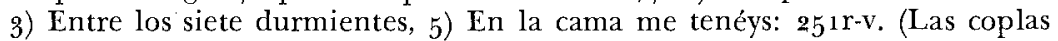
1 y 4 coinciden, salvo variantes, con 3 y 2 del núm. 326).

445. Pues el Príncipe del cielo / hecho pastorcico viene, / algo tiene acá en el suelo / que le duele. // Dies ovejas Dios crió (2): 176v. (Versión a lo divino de Antol., 64).

446. Pues eres tan lisonjera, / afuera, esperança, afuera. // 1) La esperança es vn rravioso, 2) Según la esperança es fuerte, 3) Según lo que se me alcança: $232 \mathrm{~V}$.

447. Pues mi ventura tal fue, / avnque muera, biviré, // 1) La causa de mi penar: $279 \mathrm{v}$.

448. Pues nasció la Rres preciada, / toquen y suene la caxcabelada. // Ven acá, tú, Juan Miguel (7): $155 \mathrm{v}$ s.

449. Pues por sierva os ofrecistes / y por madre os quiso Dios, / jo, Virgen, dichosa vos! // Fue tan grande la humilldad (3): $137 \mathrm{~V} s$.

450. Pues que me tienes, / mi Dios, por esposa, / mírame mira / cómo soy hermosa. // Yo soy más hermosa (2): 176r-v. (Divinización de 451).

451. Pues que me tienes, / Miguel, por esposa, / mírame, mira / cómo soy hermosa. // 1) Mira qué estremada, 2) Mi frente y mis labios, 3) Mira qué afilada, 4) Mira mis mexillas, 5) Cómo estás parlera: [295]r. (Estribillo y $1^{*}$ copla, con música, en el Canc. Medinaceli, núm. $4^{2}$. Cf. $45^{\circ}$ ).

452. Pues que no a querido Menga / querer lo que quiere Bras, / muy mala pascua le venga / si a Menga quisiere más. // 1) Bras quiere, como es rrazón, 2) Menga está desamorada, 3) Si Menga va a su ganado, 4) No se deve de culpar: $218 \mathrm{r}-\mathrm{v}$.

453. Pues que no puedo olvidarte, / el diablo aya en ti parte. // 1) Tal afición te tomé, 2) Tanto te estremó natura, 3) Hizote Dios tan hermosa, 4) Aya parte en ti $[\mathrm{y}]$ poder: $229 \mathrm{r}-\mathrm{v}$.

454. Pues que para contenplaros / estos ojos me dio Dios. . : [289]v. (Figura en B.N.P., ms. esp. 314, fol. 318r, e impreso en P. LAínez, t. 1, pp. 399 s.).

455. Puse mis amores / en Fernandillo: / jay, que era casado, / mal me a 
mentido! // 1) Fue muy desdichada, 2) Quando le era esquiva, 3) Hiziera pedaços, 4) Su palabra y fe: $[290] \mathrm{r}-\mathrm{v}$.

456. - ¿Qué contento es ése, Juan, / tras de tanto discontento? / - Bras, yo solo me lo siento. // 1) Juan, ten de mí confiança, 2) Después de tan gran pasión, 3) Por el contento en que estás: 246r-v.

457. ¿Qué de vos y de mí, señora, / qué de vos y de mí dirán?...: 24ıv. (Del Canc. general, Apéndice, 299; faltan en el ms. las coplas 1 y 2).

458. ¿Qué diré, Juan soberano, / que a vuestra grandeza quadre? / No soys Dios, mas sois su hermano, / pues sois hijo de su madre. // De vuestra grandeza digo (3) (De San Juan Evangelista): 14ov.

459. -Qué gracias tienes, Pascuala. / Qué gracioso que eres, Gil. / Biva tan linda zagala / para zagal tan gentil. // 1) Venturosa fue en mirarte: 53 r.

46o. Qué guirnalda tan galán / y quán hermosa / al evangelista Juan / le da su esposa. // De rrosas muy coloradas (3): 14or.

461. - ¿Qué hace tu magestad, / llorando, mi Dios, al yelo? / - Hago gente para el cielo. // ¿Dónde dexaste, Señor (6): [127 bis]v-128r.

462. -Qué hacéis aý, mi bien, / a tal ora a la ventana... con presupuesto / de dezirte todo el rresto (perqué de Galindo; 170 versos): 258r-259r. (Es un diálogo de insultos entre Él y Ella).

463. -¿Qué haces, honbre, di? -Estóyme calentando... (soneto): 225r. (En el Cancionero de Montemayor a partir de la ed. de Alcalá, 1563; cf. ed. Salamanca, 1579, 226r. También se atribuyó a Camoens; íniguez de Medrano lo incluyó entre sus propios "versos pastoriles" en su Silva curiosa, ed. París, 1608, pp. 79-80. Cf. RHi, 22, 1910, p. 578; RABM, 10, 1904, pp. 166 y 168 ).

464. ¿Qué harán dos que el amor halla / heridos de vna centella. . .?: 253v. (Es de Pedro de Padilla: Thesoro de varias poesias, Madrid, 1580 , $213 \mathrm{v}$ s.; son pocas las variantes del manuscrito).

465. Que perdáis el alegría, / coraçón, que amor os dio, / por que no améys otro día / donde no os mandara yo. // 1) Coraçón, bien e sabido, 2) Que biváis desesperado: [295] v.

466. - ¿Qué presentáis, Virgen, / en el tenplo vos? / -Presento mi hijo / y el Hijo de Dios. // El Verbo encarnado (3): 18or.

467. - ¿Qué se le deve al pastor / que por hallar vna oveja / todo su ganado dexa? / Bras: -Amor. // Quien de ciento del rrebaño (4): 142v.

468. - ¿Qué tienes, pastor? / ¿quién te tiene tal? / - Vn dolor mortal, / ay, ay, ay, / que me dio el amor. // 1) Yendo discuydado, 2) Amor deseoso, 3) Es lo que más siento: 2 gov $s$.

469. Quien busca gloria en la tierra / que a Dios viere / iqué más gloria, qué más quiere! // Quien busca gloria en la tierra (2): 177r-v.

470. Quien de aqueste pan comiere, / si con fe comiere dél, / mora en Dios y Dios en él. // Dios bive por fe en aquel (2): $181 \mathrm{v}$.

471. [Quien dize que el ausencia causa olvido...] (o sea, el soneto de Boscán, Obras poéticas, t. 1, 1957, p. 182). No muestra en sus concetos/estar en la que ama convertido... (glosa en liras): $204 \mathrm{v} \mathrm{s}$.

472. Quien duerme, quien duerme / que rrecuerde. // No estés discuydado (4): $89 \mathrm{r}$.

473. - ¿Quién eres, di, honbre? -Tu hechura... (soneto): 224v. (En Juan LÓPEz DE UBEDA: Cancionero, IV s.).

474. - ¿Quién es la que oy canta / la Yglesia preclara? / -Es la Virgen Clara, / pobre, humillde y santa. // Como fue vn estremo (3) (de Santa Clara): $185 \mathrm{v}$.

475. - ¿Quién está acá, / quién está aý? / -Yo soy Jesuchristo, abrí. / - ¿Qué queréis? / Abridme y saberlo eis. / -No puede ser. / -No me devéys 
conoscer. / -Bien está, estése allá, / que no puede entrar acá. // Quando el alma está en pecado (7): 165 r-v. (C.f. Antol., 113 ).

476. Quien hila y tuerçe / bien se le paresçe. // La que haze buen hilado (4 coplas zejelescas): 145 r.

477. Quien no estuviere en presencia / no tenga fe en confiança... (glosa): 277r-v. (El estribillo es de Jorge Manrigue; la glosa, de Silvestre: 86r-v, aunque se atribuyó igualmente a Juan de Almeida; cf. Anales Salmantinos, 2, 1929, p. 232. Figura anónimo en el Guisadillo de amor de Timoneda y en Flor $157^{8}$ ).

478. ¿Quién os hizo, Rrey del cielo, / honbre ser / y tan humillde nascer? // Quién hizo al Rrey celestial (3): 4 ov.

479. -¿Quién os truxo, Rrey del cielo, / a pasar tal sinsabor? / -Trúxome sólo el amor. // Vuestro poder y grandeza (3): 149v.

480. ¿Quién te hizo, Juan hermano, / sin gazajo y sin prazer, / que tú alegre solías ser? // 1) Qué's de los saltos que davas, 2) Di quién te hizo trocar, 3) $[\mathrm{Y}] \mathrm{a}$ no ves ynconvinientes, 4) En preguntar por mi mal, 5) Déxame, no me entristescas, 6) Tú me dexas de tal suerte: $202 \mathrm{r}$.

Quién te me enojó, Isabel...: véase 66.

481. Quien vive como yo bivo / sin duda podrá dezir / que ay mayor mal que el morir. // 1) Si el que biue discontento, 2) El rremedio que yo espero, 3) Si el morir es vn dolor, 4) Quando pienso morir cierto, 5) Mi muerte e vida en pelea, 6) Si muerte vençe mi vida, 7) Es mi dolor sin ygual, 8) Ay, ay, ay, dolor malino: 273r-v.

482. Quiérese morir Antón / de amores de Mirabella...: 66r-v. (En Silvestre, $113 \mathrm{r}$, con tres coplas más pero dos menos que en el ms.).

483. ¿Quiéreste casar, / pulida zagala? / Mira lo que hazes, / así Dios te vala. // 1) Si tomas marido, 2) No yrás al rrebaño, 3) Saldrán a manojos, 4) Tendrás por mejor, 5) Tendrás por consuelo, 6) Verás las pastoras: 268 r-v.

484. Quiero dormir y no puedo, / qu'el amor me quita el sueño. // ¿Cómo tengo de dormir (4 coplas zejelescas): 1 gor.

485. Quiero tomar alegría, / pues de mí Dios no se venga; / quiero tomar alegria: / mi pesar allá se avenga. // Porque fue el honbre traydor (4): 8ov.

486. Rreina de la gerarchía, / la grandeza que en vos cabe / el que la hizo la sabe. // Dévese de rremitir (3): 169v.

487. Rreina esclarecida / y madre de Dios, / virgen y parida / no la ay como vos. // Divinal crisol (7): $174^{r-v}$.

488. Rresuene bien la lira, / y canten los oyentes dulçemente... y tú jamás procuras emendarte (8 liras) (a la baxa lira): 89r.

489. Rretrato de pinzel, escoba seca, / sacado al natural acá en España... que tanto sea de mí como tú amada (soneto): $75 \mathrm{r}$.

490. Rreyes al que nasció rrey / vienen de Oriente, / y dan al dador de ley / nuevo presente. // Danle insencio [sic] como a Dios (3): 192v.

491. Rreyes vienen al Rrey niño: / |huy, hey, y qué mal aliño! // Qué buen aliño, por cierto (3 coplas zejelescas): $192 \mathrm{v}$.

492. Rribera verde vnbrosa, / prados floridos, árboles amenos... (7 liras): $58 \mathrm{v}$. (De la Égloga tercera de MonTEMayor, Segundo cancionero, 214r-215r, donde consta de 9 liras; sólo 4 coinciden en ambas versiones; hay otra versión en la Flor 1578 , pp. 174-177).

Rriberas de vn rrío está vn pastor echado...: véase 18.

493. Rriberas del Danubio a mediodía... (soneto): $227 \mathrm{r}$ y (con los tercetos condensados en un cuarteto) 73v. (Se publicó anónimo en "237 sonnets", núm. 23; aparece, atribuido a RAmírez Pagán, en B.N.P., ms. 60o, 125v; a 
Hernando de Acuña, en el Cartapacio de Pedro de Lemos, 51 r. Además se atribuyó a Mendoza y a Camoens. C.. C. Mıchä̈L1s, RHi, 22, 1910, 519521 , y $B R A E, 1,1914$, p. 159).

494. Sabé, si no lo sabéys, / que en mí más que yo podéys. // 1) Vuestro valor muy subido, 2) Perderse la libertad: 277r. (Continuación de 495).

495. Sabed, si no lo sabéys, / que n'os creo, avnque os canséis. // 1) No es posible me queráis: 277r. (Continuación de 496; cf. 494).

496. Sabed, si no lo sabéys, / que os quiero más que os queréys. // 1) Avnque vos misma os queráis, 2) Y si quisierdis saber, 3) Desde el punto en que os miré, 4) Perdíme de sólo veros: 276v. (Su continuación son los núms. 495-494).

497. Sábete, linda zagala, / que avnque estás do no te veo, / los ojos de mi deseo / sienpre contenplan tu gala. // 1) Tus gracias y perficiones, 2) Dame luz a vn dulçe engaño: $271 v$.

498. Sábete, linda zagala, / que ya es desposada Menga; / para vi [ $m i$ ? $t i$ ? ] nueva tan mala / puede ser que nunca venga (sólo eso): $194 \mathrm{v}$.

499. Salgan ya mis alaridos, / dexen puestas mis pasiones / por memoria... alcansar de mi amiga / algún rreposo (14 coplas de pie quebrado en dobles sextillas) (lamentación): $205 \mathrm{v}-207 \mathrm{r}$.

5oo. Saliendo de vna batalla / do perdió su señoría... (rromance): 227v. ( $\mathrm{Pu}$ blicado por ONTAÑón, p. 181).

5 o1. Salió de vn bosque en rrastro de vn venado / vn fiero tigre, y mientras lo buscava. . qual bolverás al triste de Felino (soneto): 226r.

502. Salió en vano mi esperança, / no sé qué rremedio tenga; / dineros pide Costança: / ¡busque la dama de dónde le venga! // 1) Fuera yo buen pagador, 2) Y ell'agora, como es niña, 3) Avn no a començado [a] amar, 4) Si el amor nada costara, 5) Bien sé yo que quien supiere, 6) Si Costança quiere amar: $71 \mathrm{v} s$.

5o3. Sálvete Dios, hermosura / de la yglesia, gran Baptista... y tú ganaste la silla (6 coplas reales) (de San Juan Baptista): $137 \mathrm{r}-\mathrm{v}$.

504. Satisfecho está ya Bras / de que Menga bien le quiere, / porque si él por ella muere, / ella por él muere más. // 1) Los ojos dulces de Menga, 2) Si Bras por Menga sospira, 3) Visita Bras los arcores: $53 \mathbf{r}$.

505. Sejáys muto enbora, / Prinçesa de a vida, / sejáis muto enbora / de vn fillo parida. // Heo so vn portugués (5): $169 \mathrm{v} s$.

Señor Gómez Arias. ..: véase $\mathbf{5}$ o6.

5o6. Señor Rrey del cielo, / duélete de mí, / que me veo presa, / y nunca en tal me vi. // Siendo yo criada (5): 148v. (Versión a lo divino de "Señor Gómez Arias...", Antol., 385).

507. Señor, tanto os humilláis, / que os baxáis de Dios a honbre, / y de Dios cobra rrenonbre / el honbre por quien baxáis. // Baxáis de Dios a ser honbre (2): $86 \mathrm{r}$.

508. Señora, el eterno Padre / os dio, porque sois tan bella, / con el gozo de ser madre / la gloria de ser donzella. // Hallóse Dios tan contento (3): 142r-v. (En Galeas, 38v).

5og. Ser vieja y arrebolarse / es dura cosa tragarse. // 1) Aquel salir de mañana, 2) Aquel dexar tan bruñida, 3) Aquel tapar la cuytada, 4) Aquel contino enrruviarse, 5) Aquel platicar con todos, 6) Aquel presumir de pechos, 7) Aquel enhoçar la toca: $222 \mathrm{v} s$.

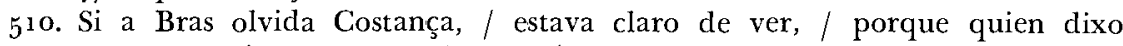
muger / mejor dixera mudança. // 1) Si Costança echó en olvido, 2) No ay de qué maravillar, 3) El pastor, de confiado, 4) A Bras Costança quería: 193r. (Probablemente del compilador).

$5^{11}$. Si a carillo vieres, / hermana mía Menga, / dile que se venga, dile [sic]. 
// 1) Por ciertos antojos, 2) No quiere más Dios, 3) Y si está enojado, 4) Dile que a su mano, 5) Dile quán rendida: $249^{r-v .}$

512. Si a los que penan por vos, / señora, ver no queréis, / con los otros, iqué haréis! // 1) Caridad, señora, hordena: zoov.

513. Si Amor está enamorado / de aquella a quien me rrendi, / mal me podrá dar a mi / lo que para sí a tomado. // 1) Si Amor de amor no muriera, 2) De Amor, para mi ventura, 3) Puse al Amor por tercero, 4) Por serme tan mal amigo: $253^{r}$.

514. Si amores me an de matar, / agora tienen lugar. // Herido vengo de amores (3): $173 \mathrm{v} \mathrm{s.}$

515. Si asi me trata el frío que tengo, / ¿qué me hará la muerte que espero?... y quien la comió, libre se queda (4 endechas "canarias", en tercetos monorrimos): 18ov. (Sobre el género de las endechas canarias cf. $N R F H$, 12, 1958, pp. 197-201).

516. Si de los ojos naçe / ver y desear, / no quiero tener ojos, / para no penar. // 1) Si vna dulçe vista, 2) Esto antes que os viera, 3) Bien pudiera yo, 4) $\mathrm{Y}$ no es desatino, 5) Mas si del tormento, 6) Ojos, mal pagáis, 7) $\mathrm{O}$, rrostro hermoso, 8) Con fe por amaros: 68r. (Sólo con la $1^{\text {a }}$ copla en CEJAdor, t. 3, núm. 2001).

517. Si de sólo verla muero, / dime qué haré, zagal: / ¿cómo le diré mi mal? // 1) Yo no sé hallar camino, 2) No ay valor para miralla, 3) Si el más s[u]bido trofeo: 7or.

518. Si de todos los que os miran / os mostráis ser servidora...: 6ıv s. (Está en B.N.P., ms. 314, $181 \mathrm{v}$, e impreso en P. LAíneZ, t. 1, pp. 398 s., alterado el orden de las 3 coplas y con muchas variantes; en CEJAdor, t. 3, núm. 2004 , sólo con la $1^{\text {a }}$ copla).

519. Si del que te quiere más, / muerte, pretendes huyr, / yo no me quiero morir: / quiçá con esto vendrás. // 1) Si al que te quiere no quieres, 2) Yo, muerte, de ti más huyo, 3) Si del que te sigue huyes, 4) Si yo te quisiera, muerte: 234 r-v.

520. Si Dios comunicase / espíritu de gracia a mi sentido... ni menos despreciada ni abatida (7 liras) (la baxa lira): igov $s$.

52 1. - ¿Si dormís, Señor? / -Ay, no duermo, non. // Mi sueño divino (4; zéjel): $172 \mathrm{r}$. (Cf. 522).

522. $-\measuredangle \mathrm{Si}$ dormís, Señor? / - Ay, no duermo, non. // Si dormis, Cordero (7; zéjel): 174 r. (Cf. 521 ).

523. Si el suspiro da pasión / del coraçón a la boca, / ¿qué hará si torna y toca / de la boca al coraçón? // 1) Avnque causa el sospirar, 2) Y avnque el suspiro entretenga, 3) Si después de aver salido, 4) Si el dolor que desatina: $254^{\mathrm{r}}$.

524. Si en el portal do nascí / comienço a padecer penas, / siendo por culpas ajenas, / ¿qué hará el honbre por mí? // Qué sobra de grande amor (6) (al tono de "Si en las tierras do nasci paso yo"): 192r-v. (Cf. Pliegos poéticos B.N.M., t. 1, p. 127).

525. Si en esta clara avsencia e de olvidarte, / olvidese la vida de quererme... la que el alma del cuerpo me diuide (soneto): $225 \mathrm{v}$.

$\mathrm{Si}$ en las tierras do nací... véase $5^{24}$.

526. Si estoy presente, me abraso, / si estoy avsente, m'enciendo: / Marina, yo no te entiendo. // 1) Qué fuego que moja más, 2) En dulçe fuego me ynflamas, 3) Yo no me puedo esconder: $236 \mathrm{r}$.

Si libres alcé mis ojos...: véase 304 .

527. Si mi padre no me casa, / yo seré escándalo de su casa...: 196v s. (En Timoneda, Truhanesco, fol. $\mathrm{x}$, con tres coplas más, pero cinco menos que en el ms.). 
528. Si mi zagala me quiere, / a la fe, quererla e yo, / y si no, que no, que no. // 1) Estoy tan escarmentado, 2) No es ya el tienpo que solía: $247 \mathrm{r}$. 529. Si no ay desamor, / no ay mal que lastime. / ¡Ay, coraçón triste!, / ¿cómo bives, dime? // 1) Vime ser amado, 2) La suerte dichosa, 3) Quitóme el contento: $248 \mathrm{v}$.

530. Si os fuérades sin quedar, / nuestro bien y nuestro Dios, / ¿quál quedáramos sin vos? // Quedáramos sin consuelo (2) (del Sacramento): 47r.

531. Si os he de querer, Silvera, / a de ser de otra manera. // 1) N'os tengo de ver quexosa, 2) ¿Ynterés queréis? N'os quiero, 3) N'os vea, que me fatiga, 4) Quando vaya a visitaros, 5) Muy gran plazer me haréis, 6) No hagáis vascas rraviosas: $235^{\mathrm{r}-\mathrm{v}}$. (Su continuación es el 119).

532. Si os pesa de ser querida, / yo no puedo n'os querer. ..: 197v s. (De GiL Polo, Diana, V; NBAE, t. 7, p. 469).

533. Si por ser la [no]che fría / no os abriga bien el heno, / venid, mi Dios, a mi seno. // Veo ser la noche fría (21/2): $84^{\mathrm{r}-\mathrm{v}}$.

534. Si por sólo ser quien soys, / vos merecéys ser servida, / ¡qué meresçeréis parida / de tal hijo como Dios! // Vuestra santidad es tanta (2): 177v.

535. Si pudiera aborreceros, / no me oviérades olvidado, / y lo que más me a dañado / a sido tanto quereros. // 1) El quereros como os quiero: $57 \mathrm{v}$.

536. - Si te me doy por comida, / di, alma, qué me darás? / -Dios mío, lo que me das: / darte e yo mi propia vida... en fe y amor derretida (8 redondillas) (de Sacramento): $183 \mathrm{v}$.

537. Si tú, carillo, supieses / la causa por que me pierdo, / yo fío que tú dixeses / que en perderme que soy cuerdo. // 1) El que perdiendo ganó, 2) Quien por ella se perdiere, 3) Perder por su hermosura: [298]r-v.

538. Si vieras, Bras, la Donzella / que a nuestro Dios a parido, / tuvieras por entendido / no aver zagala tan bella. // No se puede ymaginar (3): 189r-v.

539. Sin la fe y sin el amor / no se ve más qu'el color. // La fe nos abre la puerta (3) (del Sacramento): $47^{\mathrm{r}}$.

54\%. Sin vos y con mi cuydado, / mirad con quién y sin quién. ..: 7ov. (De SilvestRE: $111 \mathrm{~V}$ s.).

541. So la minbrera, minbrera, / so la minbrera. // So la minbrera en el huerto (10 coplas zejelescas): $175^{\mathrm{V}} \mathrm{s}$.

542. Sobre la verde yedra rrecostado... (4 cuartetos): 228v. (Está en Flor $x 57^{8}$, pp. $25^{0-2} 5^{1}$ ).

543. Sois tan grande santo vos, / Baptista, y tanto en vos cabe, / que no ay lengua que os alabe / sino sola la de Dios. // Dios, que os hizo tan privado (4) (a Sant Juan Baptista): 154 r.

544. Sola estáis, Virgen sagrada, / pero muy rregozijada. // Sola estava la donzella ( 1 ; zéjel): $93^{\text {r. }}$

Sola Francisca es causa de mi pena...: véase 390 .

545. Solas tengo yo por damas / las de mala condición, / que las otras no lo son. // 1) Damas son las rrigurosas, 2) Las que las lágrimas biuas, 3) Las blandas, enternecidas: [288]r.

546. Son tan hermosos, zagala, / esos tus rruvios cabellos, / que a la hermosura dellos / ninguna cosa le yguala (sólo eso): $233 \mathrm{v}$.

547. Soñava yo que tenía / alegre mi coraçón, / mas a la fe, madre mía, / que los sueños sueños son. // 1) Tanto soñé en mi deseo, 2) Lo que dispierto deseava, 3) Por burla[r]se Amor de mí, 4) Ordenóme que soñase: 219 .

548. Soy bonica y agraciada, / tengo gracias más de mili... $\left(=55^{2}\right)$. // 1) Gila y Venus conpetían, 2) Con sus ojos rrobadores, 3) Es verla cosa donosa: $274 \mathrm{r}$.

549. Soy del todo tan hermosa / y de gracia tan dotada, / que soi de mi Dios 
esposa / y por madre preservada. // En mi alma tengo escrito (4) (al tono de "Gila", o sea del 552): 19ov.

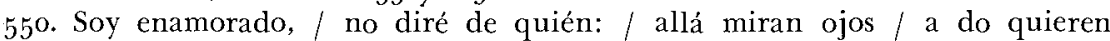
bien. // 1) Soy enamorado, 2) Yo quiero gozar, 3) Gozar de la flor: $[284] \mathrm{r}=\mathrm{v}$.

551. Soy hermosa y agraciada, / más que esmeralda y rrubí, / llámanme Virgen sagrada, / Madre del Rrey que parí. // Rreyna de consolación (5): 274v. (Otra versión a lo divino de $55^{2}$ ).

552. Soy hermosa y agraciada, / tengo gracias más de mill, / llámanme Gira Giralda, / hija de Giraldo Gil. // 1) Cierto que no tien zagala, 2) Estos mis ojos rrasgados, 3) $\mathrm{Ni}$ se vio ni se a hallado, 4) En las faldas y la espalda: $27^{21-v}$. (Es el estribillo más repetido, variado y contrahecho de nuestro cancionero; cf. núms. $54^{8}, 553,554 ; 292,549,55^{1:} 53 ; 560$ ).

553. Soy hermosa y agraciada... (=552; v. 3: mi nonbre es G. G.). $/ / 1$ 1) Mi Bartolo por guirnalda, a) El domingo que baylaron, 3) En luchar, saltar, correr: $269 \mathrm{r}$.

554. Soy morena y agraciada... $\left.\left(=55^{2}\right) . / / 1\right)$ Dende la que menos vale, 2) No sola en naturaleza, 3) Fue cosa que se dudó, 4) Dize de mí el que se atreve, 5) Tan rreqüestada y seguida, 6) Los que dicha no alcansáis, 7) Si me habla algún zagal, 8) Tienen por muy cierta cosa, 9) Porque ni la linda Elena: 62r-63r.

555. Su Hijo y la Virgen santa / anbos arden en llamas de amor; / el Niño llora y la Virgen canta / por el bien del pecador. // Estar vos, mi Dios, llorando (3): $38 \mathrm{v} s$.

556. Subid, Señora, subid, / que quien tanto se humilló / tal subida meresció. // Pues con tanto merescer (2): $144^{\mathrm{r}}$.

557. Supremo hazedor, / que tanto mis amores te an baxado... y hija del que hizo que esto cuadre (4 liras): $85 \mathrm{v}$.

558. Tal Niño y pastor / quiérole y ámole / y ámole y quiérole por señor. / Jamás se a hallado (3): 92r. (Versión a lo divino de "Madre, al Amor / quiérole, ámole, / y amo y téngole por señor", incluida en Caietain, Second livere d'airs. . Paris, 1578 , $18 \mathrm{v}$, y en otras fuentes).

559. Tan supremo rregozijo / que con Dios tiene su esposa / dinos, fe, qué's cosa y cosa. // Quál de todos los morta[1]es (3) (del Sacramento): 177r.

560. Tanto a mi Dios agradáis, / Virgen, prinçesa del cielo, / que para nuestro consuelo / dél sois amada y amáis. // El amor con que os amó (4) (al tono de "Gila Giralda"): 1gor. (A pesar de la indicación, lo que se vuelve a lo divino aquí no es el $55^{2}$, sino el 646 ; cf. 196).

561. Tanto mal, tanto mal, tanto mal / como ay en el mal; / tanto bien, tanto bien, tanto bien / como ay en el bien. // Tanto mal hizo el pecado (6 coplas zejelescas): 153 r.

562. Tanto os quiso querer Dios, / Juan, por vuestra perfición, / que no hizo donación / de su madre sino a vos. // Tanto os quiso el Sumo Padre (2) (del Evangelista): $186 \mathrm{r}$.

563. Tañendo está Pardalio en vna fuente / su gaita o su sanpoña de ora en ora... ten ya por bien de darme algún contento (soneto): $74 \mathrm{v}$.

564. Tendido al pie de vn sauze en el arena, / en la dura rais mal rrecostado... le diese, pues la vida le desplaze (soneto): 27 $\mathrm{rr}$.

565. Términos lleva María / de dar cabo y fin de Bras, / porque él va queriendo más, / y ella menos cada día. // 1) Es María tan cruel, 2) Si porfía a ser tan dura, 3) A María Bras amando, 4) María quiere hazer, 5) Bien que solía querer, 6) Bras fuera mejor librado, 7) Llora y suspira el pastor: 69r-v. (Cf. 97 y 20).

566. Tiraban al más certero / ynterés y el Amor franco...: 255r. (Está en el 
Truhanesco de Timoneda, fols. xj-xij, y, con dos coplas más, en P. LAínez, t. 1, pp. 442-443, tomado de B.N.P., ms. esp. 314, fols. $223^{\mathrm{r}-224 \mathrm{r}) \text {. }}$

$5^{6} 7$. Tiráos allá, desengaños, / no vengáis, / a tienpo que no prestáis. // Desengaños, ya m’ensaño / en verme de vos cercado... (glosa): $22 \mathrm{ir}-\mathrm{v}$.

568. Toda sois, Virgen, hermosa, / sin aver mácula en vos, / porque así os eligió Dios. // Criada fuestes, Señora (4): $173 \mathrm{v}$.

569. Tomándole están la jura / a Cipión Africano. . (rromance): 257r. (Impreso por OnTañón, p. 184).

570. - Torna, Mingo, a enamorarte. / - ¿Guarda fuera! / antes yo de rravia muera. // 1) Mingo, torna a tus amores, 2) No te podrá maltratar, / 3) Pues entiendes, Mingo, tu daño, 4) Quieres mudar el pellejo, 5) No hallo cómo te entienda, 6) Mi fe, no quieres sanar: [287] v $s$. (Cf. 571).

571. - Torna, Mingo a enamorarte. / -iOxe, afuera!, / antes yo rraviando muera. // 1) Mingo, torna a tus amores, 2) No te podrá maltratar, 3) Pues en algo as de enplear, 4) Pas [¿pues?] que solías baylar, 5) Podrá ser que te verá, 6) [Tú] tienes el seso poco, 7) Anda, tú lo buscarás: [299]r-v. (Cf. $570)$.

572. Tristeza, si me dexares, / hará fin la vida mía, / y acabarse a el alegría / acabados los pesares. // 1) El rremedio de otra pena, 2) Siendo, pues, la ocasión tal: $264 \mathrm{r}$.

573. Trocado se avía la suerte, / y Menga llora. / Llore y muera mala muerte / tan ynconstante pastora. // 1) Amada fue y amó ella, 2) Pelayo por Menga ardiendo, 3) Está Menga acobardada, 4) Del mal que ella le hazía: $267 \mathrm{v}$.

574. Un abraço me mandó [sic] Ynés / baylando allá en el aldea. .: 65v. (De

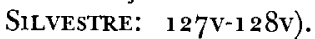

575. Un grano vino del cielo, / que el Padre eterno enbió, / que plantado acá en el suelo / muy más de a ciento acudió. // Senbróse aquesta semilla (8): i 32 r-v.

576. Un hijo, mi amor, que [a] avido / de David, Amón llamado... (romanze): 57v. (En Ontẫón, p. 187).

577. Un pastor enamorado / que oy nos a venido acá / por silvos suspiros da. // Christo, pastor verdadero (3): i $87 \mathrm{v}$.

578. Un Zagal de alto lugar / - no lo puedo dezir de rriza- / qu'es nascido nos avisa / el que nos viene a levantar. // Quanta fue nuestra caída (4) (al tono de "Vna moçuela deste lugar", o sea el núm. 581): igiv $s$.

579. Una cárcel esquisita / do están presas muchas gentes. . diga "Consumatum est” (ensalada): 158r-159r. (Cf. núms. 84, 107, 228, 311 y 441).

58o. $-U$ na duda tengo, Juan. / -Declárala, si quisieres. / -Si no piden las mugeres, / ¿de qué se sustentarán? // 1) Con solos suspiros vanos, 2) Cómo podrán sacar ama, 3) Escofiados y almirantes, 4) Suspiros, quexas y lloro: 234r. (Es continuación del 146).

581. Una moça deste lugar / - no lo puedo dezir de rriza- / no tiene faldas de camisa / y pide rropa de levantar. // 1) Por cosa muy verdadera, 2) Vn día la vía labar, 3) Por cierto que es avisada: 193v s. (Las coplas parecen ser del compilador. Cf. 578).

582. Una Virgen pura / oy a Dios pariera / y quedara entera. // El mundo se espante (5): $133^{\mathrm{r}-\mathrm{v}}$ y (con música y sólo una estrofa) $52 \mathrm{r}$.

$5^{83}$. Unos me dizen que vaya / y otros me dizen que no, / y otros que por qué no vo. // La rrazón me dize ve (5): 134r.

584. Vamos al portal, / amigo Silvano, / donde está vn Zagal / divino y humano. // Anda [a]cá, verás (4): 4ir-v.

58. Vamos, Gil Vicente, / a Belén por tu fe, / para ver a los Rreyes de Oriente, / y holguémonos, ¡e! // Verás en la villa (4): ı $80 \mathrm{v} s$. 
586. Vanse mis amores, / quiérenme dexar, / avnque soy morena, / no soy de olbidar. // 1) El que yo más quiero, 2) Dónde vas, traydor, 3) Di, qué pretendiste, 4) Si de alguna estavas, 5) Más blanca y hermosa, 6) El hermosa ser: 2ogv.

587. Vase Dios, mi amor, / muérome por él; / él me trayga a tienpo / de verme con él. // Viene a rremediarme (3): 199v. (Versión a lo divino del 588).

588. Váseme mi amor, / muérome por él; / Dios lo trayga a tienpo / que me vengue dél. // 1) Pártese de aquí, 2) Si de su partida, 3) De su poca fe, 4) Si el amor me fuera: $[285]$ r. (Cf. 587 ).

589 . Ve do vas, mi pensamiento, / enbidia tengo de ti, / pues verás el bien que vi / sin sentir el mal que siento. // Agradable conpañía / haze la ymaginación... (glosa): 2o7r. (Coincide parcialmente con la versión del Sarao de amor de Timoneda, Valencia, $\left.15^{61}, 36 \mathrm{v}\right)$.

590 . Véante mis ojos, / muérame yo luego. ... [296]r. (De Montemayor: Las obras, 18r; faltan en el ms. los vs. 11-12 y 19-20. Cf. 591).

591. Véente mis ojos, / Dios y honbre en el suelo, / dulçe amor mío / y todo mi consuelo. // Toda la tristeza (3): 168r. (Cf. 590).

592. Ven, oveja, donde estoy, / que buen pastor soy. // Casárame mi padre... (romance con estribillo): $138 \mathrm{r}$. (Son los 32 versos iniciales de la primera de las "Canciones, chançonetas y villancicos" publicados como de FerNán GonzÁlez dE Eslava junto con sus Coloquios en 1610; cf. ed. Icazbalceta, México, -1877, pp. 239-240).

593. Venga y vaya, / que Lucifer ya desmaya; / vaya y venga, / que Lucifer ya tiene mengua. // Humillado (4): 84 r.

594. Vengo de ver vn Zagal / del honbre tan namorado, / que muere por el pecado, / sin aver él hecho el mal. // Bien es tal Zagal se nonbre (3): $147 \mathrm{r}$.

595. Vengo mal ferido, / ferido vengo, / ferido me an / amores que tengo. // Vide vna Donzella (2): $138 \mathrm{v}$.

596. Venid a llorar, pastores, / a carillo, el malogrado, / pues de puro enamorado / lo acabaron sus amores. // 1) Quiso tanto vna zagala, 2) Quando en más plazer se vía, 3) Parescióme quando vi, 4) Apretándome la mano: [287]r.

597. Venid, pastores, / vamos a Belén, / a ver la Pastora, / a ver el Pastor / donde mana el bien. // La gentil Pastora (2): 128v $s$.

598. Veôs tan cerca de Dios, / que si por la fe no fuera, / yo, Juan, por Dios os tuviera: / tanto os pareçéis a Dios. // Quien ve que tanto priváis (4) (a Sant Juan Evangelista): 149 r.

599. Vestirme quiero agora vn trizte luto, / la trizteza será mi conpañía... (6 octavas) (glosa a la prinçesa de Lerma sobre el pie que dize "Yo me

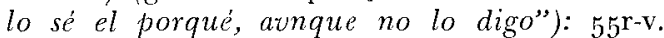

60o. $V$ i tesoros ayuntados / por gran daño de su dueño... jentes de todos estados: $34 \mathrm{v}-37 \mathrm{v}$. (Es el Doctrinal de privados del Marqués de Santillana; cf. Canc. general, núm. 53).

601. -Vicente, ten gran prazer, / que la vida es por nos. / -¿Quién la halló? -Vna muger / que tiene vencido a Dios. // Dios, soberana potencia (2): $146 \mathrm{v}$.

6o2. [Vide a Juana estar lavando...]. En vn lugar sonoroso... (glosa): $254 \mathrm{v} \mathrm{s.}$ (Figura en el Guisadillo de amor de Timoneda, fols. vj-vij).

6og. Vide vna Donzella / de admirable ser / con vn Niño en braços, / qu'es cosa de ver. // Vide vna Donzella (3): 139v y (con música y sólo una estrofa) $52 \mathrm{r}$.

604. Vídela en vn portal / a la Virgen linpia y pura; / puédome yo llamar / dichoso y con ventura. // La çarça que ardía (4): $93 \mathrm{v} s$. 
605. Vine yo, mi madre, / al mundo salvar, / vestíme de carne / por disimular. // Pudiera traer (4): ı6ov s.

6o6. Virgen, de Dios fuestes dina, / tanto que por vuestra mano / a Dios hezistes humano / y a vos hezistes divina. // Cupo en vuestro meresçer (2): $134 \mathrm{v}$.

607. Virgen, pues que en este suelo / paristes al mismo Dios, / vuestro sacro vientre es cielo: / luego cielo vuo entre nos. // Si en vuestro vientre sagrado (2): $85 \mathrm{v}$.

6o8. Virgen, si al pie la cruz / pasastes dolor de muerte, / todo en gloria se convierte / por rresusitar Jesús. // Si en la cruz, Virgen María (1): 15 lr.

6og. Virgen soberana, / bien seáis parida, / pues parís la vida. // Por Eva la muerte (3) (al mismo tono del 610): $188 \mathrm{r}$.

610. Virgen soberana, / oy abéis parido / al Rrey prometido. // Nuestro primer padre (4) (al tono “Ojuelos graciosos”, o sea del 387 ): $187 \mathrm{v} \mathrm{s}$. (Véase el núm. anterior).

611. Viva, biva nuestro estado, / libre de amoroso ardor: / queme mal fuego al amor / y al que fuere enamorado. // 1) Muera el amoroso fuego: $231 \mathrm{v}$

612. Voyme atendiendo, / por no me morir. // 1) Madre, vn pastorcico, 2) Díxome: -Pastora, 3) (incompleta) Ten de mí [me]moria: [292]r.

613. Vuestro amor, Señora, / vi en Belén estar: / pastorcico lo dexo / dentro en vn portal. // Lindo es el Donzel (11) (al tono "El tu amor, Juanica"): 13ov-131v. (Cf. 220).

614. Ya de tus errores, / Lucifer, no fies; / ya es tienpo que llores / si algún tienpo rries. // Ya no enpeȩerá (6): $157 \mathrm{v}$ s. (Versión a lo divino del 159; cf. 154).

615. Ya Dios es nascido, / hermano mío, Bras, / en Belén lo dexo, / do lo hallarás. // En Belén lo vi (8) (al tono de "Molinero lo dexo"): $166 \mathrm{v} s$. (Cf. 220).

616. Ya el sol es salido / y la luz es día. / Vamos a ver Madre / que tal Hijo cría. // Vamos y veremos (4): $159 \mathrm{v} s$.

617. Ya murió el mal, / pecador, nada te pene, / pues el gozo divinal / del sielo te viene. // Ya peresció (3): 9ir.

618. Ya no ay noche, todo es dia, / pues el que la luz crió / en esta noche nació / por darnos nueva alegría. // Nacen Dios y honbre junto (4): $161 \mathrm{v}$.

619. Ya no quiero ser vaquero / ni pastor, / ni quiero servir al amor. // 1) Si no guardara ganado, 2) Soliame yo holgar, 3) Yo apasentava vn rrebaño, 4) Agora lo dexo yr, 5) [Ú]boseme de perder, 6) Yo la vi que se lavava, 7) Atentos hazía estar, 8) Yo viendo que mi esperanęa: 202v $s$.

620. Ya no tiene más que dar / Dios a el honbre por comida / que a su sangre por beuida / y su cuerpo por manjar. // Junto todo Dios lo a dado (5): $46 \mathrm{r}$.

621. Ya paresció la Virgen entera, / ya paresció, que bien paresciera. // Mingo, Bras y Gil Mathía (3): $46 \mathrm{v} s$.

622. Ya rrecojo mi ganado, / tornarme quiero pastor: / mal fuego queme al amor. // 1) A Dios, Libea, te queda: [283]v.

623. Ya se a desposado nuestro Amo, / ya se a desposado. // Nueve meses a (5): 135r. (Basado en el "Ya soy desposado, / nuestramo, / ya soy desposado" de Juan del Encina).

624. Yéndome y viniendo / fuyme enamorando; / començé rriendo / y acabé llorando. // 1) Yo fue servidor, 2) Quando estoy delante, 3) Llama ella flaqueza: 202r-v. 
625. Yo bien puedo ser casada, / mas de amores moriré. // 1) Quando me ayan de casar, 2) Por bien que sea casad[a], 3) Tañan en el cielo arriba, 4) Pongan tanbién sobre mí, 5) Con epitafio dorado, 6) Guardando mi monumento, 7) $\mathrm{Y}$ si al tercero día: $261 \mathrm{v}$.

626. Yo lloré rriberas deste rrío [sic], / dezía vn pastor cantando discuydado... murió en los braços de su Galatea (7 octavas): 266r-267r. (Es continuación o más bien réplica del 17).

Yo me lo sé el porqué...: véase 599.

627. Yo's juro, a fes, amor, que si os cojese / en parte do no oviese valedores... y si abaxáys, guardáos, que estoy quexoso (soneto): $75 \mathrm{v}$. (Distinto de "Amor, yo os juro a Dios que si os cogiese", sobre el mismo tema, publicado como de Vadillo en las Obras de Cetina, t. 2, p. 245, y anónimo en "237 sonnets", núm, 183).

628. Yo sola a Gileta quiero, / los demás quieran a Menga; / sólo por Gileta muero, / lo demás allá se avenga. // 1) Yo sólo muero por ella, 2) Si Menga mirando hiere, 3) Partes tiene Menga cierto, 4) La suma de hermosura: $193^{\mathrm{r}-\mathrm{v}}$.

629. Yo soy vuestra madre, / mi hijo y señor, / mi hijo y mi amor. // Yo soy vuestra madre (4): $154 \mathrm{v}$.

63o. Yo suelo con tu memoria, / señora, salir de mi, / y quando contenplo en ti / no puedo tener más gloria. // 1) Dulçe cosa es contenplar, 2) Poco soy para quien eres, 3) Escusado es rreferir: $262 \mathrm{r}$.

631. Yo vi, estando en mi sentido, / que en vn sepulcro çerrado... (1 copla real) (enigma de el niño en el vientre): $215^{\mathrm{r}}$.

632. Yo vi vn honbre siego y mudo / estar por los pies colgado... (1 copla real) (enigma de la sonbra): $2{ }_{5} 5^{\mathrm{r}}$.

633. Yo vi vnos que peleavan, / levantados de la tierra... (2 coplas reales) (enigma del juego del axedrés): 215 r.

634. Zagal, alegre te veo / y tu fe firme y segura...: [293]v. (De la Diana de Montemayor, VI; pp. 267-269).

635. -Zagal, muy libre te veo, / ¿qué as avido con amor. .? 264v. (De MoNTEMAYOR: Segundo cancionero, $42 \mathrm{r}-\mathrm{v}$ ).

636. -Zagal, no sé qué te veo, / qu'estás de senblante triste. / -Dime a quién alegre viste / avsente de su deseo. // 1) Quién bastante puede ser, 2) Si tú tienes sentimiento, 3) No tienes, zagal, rrazón: $222 \mathrm{r}$.

637. -Zagal, por lo que te quiero / me pesa de verte así. / -No burles, Ana, de mí, / pues sabes que por ti muero. // 1) Carillo, pena ynportuna, 2) Qué quies que haga, garçón, 3) Mira que te tiene amor, 4) Quando yo a [o]tro zagal quiera: $219 \mathrm{v} s$.

638. Zagala, cuán libre estás, / quán contenta, leda y fría, / espero en Dios que algún día / casarás y amansarás. // 1) De no tener sujeción, 2) $\mathrm{Pa}$ saráse esta verdura, 3) Si piensas bivir soltera, 4) Las yras, las asperezas, 5) Si el yugo de ser amada, 6) Allí me veré vengado: [294]r-v. (Cf. 639).

639. Zagala, cuán linda estáis, / tan humillde, alegre y bella; / veros madre y ser donzella / plazer y contento dais. // Zagala rresplandeciente (4):

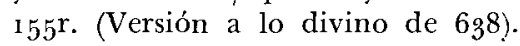

640. Zagala, cuando me veo / sin ti, solo en mi ganado, / peno, y más enamorado. // 1) Quando voy allá al lugar, 2) Acreciéntase el deseo, 3) Yo temo si otro pastor, 4) Querría saber, zagala, 5) Contenplando tu figura, 6) Acá en estos verdes prados, 7) Entre las verdes moreras, 8) Las claras fuentes y amenas, 9) Ay, qué "ay" $\tan \sin$ sosiego, 1o) Zagala, quiero dexar: $260 \mathrm{r}-\mathrm{v}$.

641. -Zagala [sic], dame rrehenes / de que no me olvidarás. / -Zagala, tú te los tienes, / que no te puedo dar más. // 1) Para qué quieres rehenes, 
2) No te admire, mi carillo, 3) Mi cuerpo y mi coraçón, 4) No tengo más qué te dar, 5) Ten por cierto y verdadero: 26or.

642. -Zagala de lindo gesto, / háblame por Dios vn día. / -Carillo, no me es onesto, / ni puedo, que no soy mía. // 1) Por ser hermosa y graciosa, 2) Cúya eres saber quiero, 3) El hablar por cosas feas: [287]r-v.

643. -Zagala, di qué harás / desque veas que soy partido...: [298]r. (De

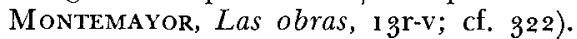

644. Zagala, $1[0]$ s tus cabellos / de oro son, / y de azero el coraçón / que no se muere por ellos. // Por mill maneras amor / haze guerra quando quiere... (glosa): [282]r.

645. Zagala más que las flores, / blanca, rruvia y ojos verdes, / si as de tomar amores, / piérdete bien, si te pierdes. // 1) Zagala y ánima mía, 2) Tus ojos solos an sido: [288]v.

646. Zagala, no me agradáis, / vais y venís al aldea, / andáis triste y no sois fea: / dóme a Dios si vos no amáis. // 1) Discuydada andáis vagando, 2) Con trabajo andáis de fiesta, 3) Con esta nueva herida, 4) Atrevida y temerosa, 5) Paresçe qu'están trocados: 64v s. (Cf. 647; 196, 560).

647. Zagala, no me agradáis... $(=646)$. // 1) Zagala, mal me paresçe, 2) Veos canbiado el senblante, 3) Seguís collados y alcores, 4) De poco acá aborresçéys, 5) Júsgame por tu yntención, 6) Pues que parte es mi tristeza: $276 \mathrm{r}-\mathrm{v}$.

648. -Zagala, ¿por qué me dexas, / pues no te lo merescí? / -Poco me afligen tus quexas, / pastor, que libre nascí. // 1) No te muestres tan esquiva, 2) O qué poco te a durado, 3) Yo me acuerdo que te vía, 4) Zagala, qué's de las cartas, 5) Pues Dios te hizo hermosa, 6) Como a tus ojos me amavas, 7) Mirávasme como a espejo, 8) Yo no sé quién te trocó, 9) No te quiero más hablar: 26ir-v.

649. Zagala, pues que me parto, / todo el bien quede contigo, / y el mal se vaya comigo. // 1) Avnque voy por el camino, 2) Ya yo me voy y te dexo: [296]r.

650. -Zagala, ¿qués de la fe / que me prometiste, di? / -Carillo, mía no fue / la culpa, sino de ti. // 1) Zagala, presto quesiste, 2) Fementida te dirán, 3) Maldito sea el memento, 4) Tus halagos y promesas, 5) Dime, por qué quebrantaste, 6) Al fin no me maravillo: [285]r-v.

651. -Zagala, ten por contento / dar rremedio a mi cuydado. / -Zagal, con el pensamiento / que tienes estás pagado. // 1) Zagala, juzga mi fe, 2) El amor no está en rrazón: $5^{6 \mathrm{v}}$.

652. Zagala, tomad pastor, / y si no lo oviere al justo, / amor lo ará a vuestro gusto, / y así sabréys qués amor. // 1) Sabed que la hermosura, 2) Qué aprovecha ser hermosa, 3) La hermosura y beldad: $253^{\mathrm{r}-\mathrm{v}}$.

653. Zagaleja de lo verde, / tan graciosa en el mirar, / quédate a Dios, alma mía, / que me voy deste lugar. // 1) Yo me voy con mi ganado, 2) Yo me voy, pues tú lo quieres, 3) Voyme desfavorescido, 4) Yréme por la(s) montaña, 5) No quexaré la pasión: [289]r. (Estribillo y $1^{a}$ copla coinciden con Flor de enamorados, 103r).

654. Zagales, estoy mortal / de amores de Catalina, / que le di vna clavellina, / y ella diósela a Pascual. // 1) Con la gloria que sentía, 2) Y si celos an podido, 3) Y con averme jurado, 4) Pedíle vna ves o dos: $249 \mathrm{v}$.

$6_{55}$. Zagales, herido vengo / de vn mal que no tiene cura, / que a de sanar por ventura, / y aquésa yo no la tengo. // 1) Traygo herido el coraçón, 2) Ventura túvela yo: $22 \mathrm{lv}$.

656. Zagales, $i d$ al portal / y veréys vna Zagala, / hermosa, así Dios me vala, / . parida con vn Zagal. // Vna Zagala hermosa (7) (al tono de "Dexa' mi mal'): $167 \mathrm{r}-\mathrm{v}$. 
657. -Zagales, sin sezo vengo. / - ¿Qué as, pastor? / -Que enbíe el divino Amor, / para rreparar al honbre, / a vn Niño por rredentor. // Vn Niño de tal potencia (3): $156 \mathrm{v}$.

658. Zape d'un gato, çape, / çape d'un gato. // Çape, çape, Berzebú (4 coplas zejelescas): $149 \mathrm{v} s$.

\section{INDICE DE FORMAS MÉTRICAS (EXCLUYENDO LOS VILLANCICOS)}

coplas de arte menor: 19,600

coplas castellanas: $71,211,4^{01}$

coplas reales: $55,129,130,210,235,281$, $295,351,373,415,422,503,631,632$, 633

coplas de pie quebrado: $65,70,227,299$, 499

quintillas: $\mathbf{2 8 8}$

redondillas: $303,412,536$

romances: $1,44,95,96,118,132,134,13^{8}$,

$140,151,181,214,228,229,247,267$,

$27^{6}, 315,317,35^{\circ}, 416,424,426,427$,

$500,569,576,592$

perqués: $28,46,4^{62}$

ensaladas: $\mathbf{5 7 9}$

zéjeles: $2,37,83,117,153,173,176,212$,

$213,225,243,270,305,345,349,371$,
$37^{8}, 39^{\circ}, 4^{06}, 47^{6}, 4^{84}, 491,5^{21}, 522$, $541,544,561,658$

glosas (en diferentes metros): $27,76,110$, $111,182,238,249,285,286,300,399$ $413,414,439,471,477,567,589,599$, 602,644

sonetos: $4,13,15,29$ (?), $3^{0}, 34,3^{8}, 43,54$, $67,127,148,161,163,166,194,205$, $232,244,245,255,261,302,360,(376)$, $393,463,473,489,493,501,525,563$, 564,627

cuartetos: 18, 167, 273, 493, 542

tercetos: $72,178,364,43^{1}, 5^{15}$

liras: $21,128,375,3^{8} 3,4^{14}, 47^{1}, 488,492$, 520,557

sextetos-lira: $62,429,43^{6}$

octavas: $16,17,98,330,599,626$

\section{INDICE DE AUTORES}

Acuña, Hernando de: 493

Alcázar, Baltasar del: 239; cf. $4^{15}$

Almeida, Juan de: $4, \mathbf{1 3}, 477$

Badajoz, Garci Sánchez de: 299

Boscán, Juan: 471

Camoens, Luis de: 463,493

Cetina, Gutierre de: 205, 232

Galeas, Francisco: $203,246,323,33^{8}, 421$, $431,440,5^{08}$

Galindo: 462

Gallegos: 415

Gil Polo, Gaspar: 124, 532

González de Eslava, Fernán: 592

Hurtado de Mendoza, Diego: 139, 376, 409,493

Iñiguez de Medrano, Julio: 412,463
Montemayor, Jorge de: $13,36,45,57,9^{8}$, $102,116,125,145,177,185,244,245$, $302,368,385,389,396,401,463,492$, $590,634,635,643$

Padilla, Pedro de: $44,127,464$

Pérez de Guzmán, Hernán: 19

Ramírez Pagán, Diego: 148, 163, 232, 493

Román, Comendador: 70,227

Sánchez de Badajoz: 299

Santillana, Marqués de: 65,600

Silvestre, Gregorio: 41, 74, 171, 208, 210 $285,301,312,353,357,374,377,434$, $477,4^{82}, 54^{\circ}, 574$

Timoneda, Juan: $190,477,527,566,5^{89}$ 602

Vadillo: 627

ADDENDUM.-En Un cancionero bilingüe ms. de la Biblioteca de El Escorial descrito

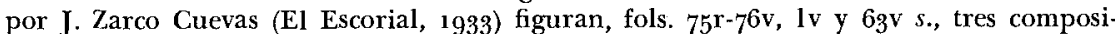
ciones de nuestro ms.: $x$ ) el núm. 17, integro, con variantes, seguido de una glosa de sus 2 primeras octavas, distinta de nuestro núm. $18 ; 2$ ) el soneto glosado parcialmente en el núm. 414 (está también en B.N.P., ms. 6o2, fol. 179); 3) las 3 primeras octavas del núm. 599, seguidas de 4 octavas distintas (versión coincidente con la descrita en $B R A E, 12,521-522)$.

NotA.-En el Vergel de canciones antiguas que editará próximamente la Editorial Planeta de Barcelona (colección Clásicos "Planeta"), publicaré 37 textos del Cancionero sevillano: los núms. 11, 25, 58, 73, 83, 117, 158, 212, 219, 276, 289, 305, 326, 332, 334, $335,34^{1}, 363,439,45^{0}, 45^{1}, 455^{6}, 47^{2}, 47^{6}, 4^{84}, 5^{06}, 5^{14}, 54^{1}, 55^{8}, 579,5^{86}, 5^{87}, 5^{88}$, $591,613,621$ y 625 del presente Indice. Estoy preparando, por otra parte, la edición íntegra del manuscrito. 